\title{
REVIEW
}

\section{Mechanisms linking the renin-angiotensin system, obesity, and breast cancer}

\author{
Fahmida Rasha1,2, Latha Ramalingam1,2, Lauren Gollahon1,2,3, Rakshanda Layeequr Rahman2,4, \\ Shaikh Mizanoor Rahman1,2, Kalhara Menikdiwela1,2 and Naima Moustaid-Moussa1,2 \\ 'Department of Nutritional Sciences, Texas Tech University, Lubbock, Texas, USA \\ 2Obesity Research Institute, Texas Tech University, Lubbock, Texas, USA \\ ${ }^{3}$ Department of Biological Sciences, Texas Tech University, Lubbock, Texas, USA \\ ${ }^{4}$ Department of Surgery, School of Medicine, Texas Tech University Health Sciences Center, Lubbock, Texas, USA \\ Correspondence should be addressed to N Moustaid-Moussa: naima.moustaid-moussa@ttu.edu
}

\begin{abstract}
Obesity is a complex disease and a global epidemic. It is a risk factor for other chronic diseases including breast cancer, especially in women after menopause. Diverse etiologies underlie the relationship between obesity and breast cancer. Adipose tissue is in part responsible for these interactions. In obesity, adipose tissue undergoes several metabolic dysregulations resulting in the secretion of many pro-inflammatory cytokines, growth factors, and hormones which in turn, can promote tumor microenvironment (TME) formation and cancer progression within the breast tissue. Angiotensin II (Ang II) is a well-known hypertensive hormone produced systemically and locally by the reninangiotensin system (RAS). Activation of this system in obesity is a potential contributor to local and systemic inflammation in breast adipose tissue. Ang II actions are primarily mediated through binding to its two receptors, type 1 (AT1R) and type 2 (AT2R). RAS inhibitors include angiotensin-converting enzyme inhibitors (ACE-I) and angiotensin receptor blockers (ARBs) which are currently prescribed as safe antihypertensive therapies. Recent studies have explored the potential use of ACE-I and ARBs in breast cancer patients as anti-tumor agents. Therefore, it is vital to understand the role of RAS in breast cancer and identify mechanisms of Ang II and RAS inhibitors in the TME and in obesity and breast cancer crosstalk. In this review, we performed a detailed analysis and discussed mechanisms of Ang II-AT1R interactions in breast cancer with emphasis on obesity-associated breast cancer. We further summarized recent in vitro, in vivo and human studies that used ACE-I/ARB interventions to improve breast cancer outcomes.
\end{abstract}

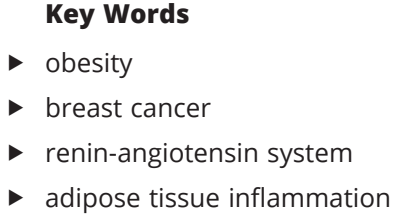

Endocrine-Related Cancer (2019) 26, R653-R672

\section{Introduction}

Breast cancer $(\mathrm{BC})$ is the most common type of cancer among women worldwide (George et al. 2013) and the second leading cause of cancer deaths in US women (Suganuma et al. 2005). Additionally, one in eight US women have a lifetime risk of developing BC, with approximately 40,920 deaths due to breast cancer in 2018 (Suganuma et al. 2005). Obesity is a complex health condition and contributes to $20 \%$ of all cancer-related mortality (Pierobon \& Frankenfeld 2013, Simpson \& Brown 2013). Evidence shows that excessive weight gain, especially in women after menopause, doubles the incidence of BC (DeSantis et al. 2014). Interestingly, raising BMI by 5 units increases the risk of receptor-positive BC by $33 \%$ in women after menopause (Suzuki et al. 2009). 
However, the underlying mechanisms linking obesity and $\mathrm{BC}$ are still unclear and require further investigation to identify novel mediators of this interaction, which could pave the way for future BC therapies, especially for women suffering from obesity. In addition to adipocytesecreted hormones, growth factors and cytokines, another potential contributor to the development of the tumor microenvironment, in part through increased adipocyte secretory activity, is the renin-angiotensin system (RAS). Our laboratory and others have reported that angiotensin II (Ang II), the major bioactive peptide hormone of the RAS pathway increases fatty acid synthesis and inflammation in adipocytes (Kalupahana et al. 2012). Thus, RAS, and specifically Ang II, may potentially contribute to the negative metabolic effects of obesity on BC (Vinson et al. 2012). RAS inhibitors (angiotensin-converting enzyme inhibitor, ACE-I and angiotensin type I receptor blocker, ARBs), clinically used to treat hypertension, have been proposed as prospective therapeutic agents in managing obesity-associated BC (Pituskin et al. 2011). In this review, we dissect the possible mechanism(s) of RAS in obesity and $\mathrm{BC}$ crosstalk.

\section{Key modulators of obesity and $\mathrm{BC}$ interactions}

Human breast tissue is primarily composed of adipose, glandular and connective tissues. Thus, adipose tissue in the breast has a potentially major role in determining BC risk (Pettersson \& Tamimi 2012). In obesity, adipose tissue expansion is associated with increased secretion of several pro-inflammatory cytokines, which in turn induce local as well as systemic inflammation (Saely et al. 2012). This may subsequently increase $\mathrm{BC}$ risk by promoting a toxic microenvironment favorable to cancer cell growth and metastasis.

Various mechanisms have been proposed (Himbert et al. 2017) such as (1) increased estrogen production in breast adipocytes due to enhanced aromatase activity, leading to estrogen receptor-positive (ER+) BC development (Bulun et al. 2012); (2) secretion of proinflammatory adipo-cytokines such as interleukin-6 (IL-6), tumor necrosis factor alpha (TNF- $\alpha$ ), and monocyte chemoattractant protein-1 (MCP-1), by hypertrophic obese adipocytes resulting in the development of malignant phenotypes (Lorincz \& Sukumar 2006); (3) increased levels of insulin and insulin-like growth factor-1 (IGF-1) in obesity, which are the main influencers behind developing abnormal mitogenic capabilities in epithelial cells (Stephenson \& Rose 2003). Below, we briefly discuss some key modulators of obesity and BC interactions.

\section{Role of inflammatory adipo-cytokines}

Inflammatory responses are found to contribute to 15-20\% of all cancer-related deaths (Balkwill \& Mantovani 2001, Balkwill et al. 2005). Increased adipose hypertrophy due to obesity is positively correlated with recruitment of inflammatory immune cells to adipose tissue (Monteiro \& Azevedo 2010). Metabolic alterations due to obesity facilitate secretion of many pro-inflammatory cytokines like TNF $\alpha$ and IL-6 via Toll-like receptor (TLR)-mediated signaling and nuclear factor kappa $\mathrm{B}$ (NF-кB) activation (Zahid et al. 2016). Increased TLR and NF-кB interactions have been associated with increasing cancer stemness in BC (Rinkenbaugh \& Baldwin 2016). Several cytokines implicated in these inflammatory conditions are discussed below.

IL-6 secreted by adipose-derived stromal cells promote $\mathrm{BC}$ cell migration and invasion via a variety of signaling pathways including p38 (mitogen-activated protein kinase kinase, or MAPK), janus kinase (JAK2), and signal transducer and activator of transcription 3 (STAT3) to control cell metabolism and proliferation. IL-6 further promotes prostaglandin E2 (PGE2) production and cyclooxygenase 2 (COX 2) generation in BC cells, thus upregulating cancer cell proliferation, survival and angiogenesis (Walter et al. 2009, Himbert et al. 2017).

Interleukin (IL)-8 is another major adipo-cytokine produced mainly by macrophages and monocytes where it activates similar inflammatory pathways like IL-6 (Baggiolini et al. 1995). Furthermore, IL-8 is involved in chemoattraction and leukocyte recruitment in adipocytes (Himbert et al. 2017); thus, it has a direct role in angiogenesis via increased endothelial cell proliferation and survival, and cancer metastasis via induced matrix metalloproteinase expression (Todorović-Raković \& Milovanović 2013). Though IL-8 is a marker of ER- BC, it could enhance invasiveness of both ER- and ER+ BC (Todorović-Raković \& Milovanović 2013) as it is associated with other pro-inflammatory cytokines like interleukin-32 (IL-32) to induce extracellular matrix (ECM) remodeling and metastases of in vitro cancer cells (Catalán et al. 2017).

MCP-1, also known as chemokine ligand 2 (CCL2), actively recruits circulating monocytes to the tumor site, which are later differentiated into tumorassociated macrophages (TAM) thereby promoting tumor microenvironment (TME) (Correa et al. 2017).
(C) 2019 Society for Endocrinology Published by Bioscientifica Ltd. Printed in Great Britain 
This, in turn, increases infiltration of immune-suppressive myeloid-derived suppressor cells (MDSCs) and is associated with poor tumor prognosis ( Picon-Ruiz et al. 2017).

$\mathrm{TNF} \alpha$, a major pro-inflammatory cytokine secreted by obese adipocyte-derived macrophages, can have both growth-promoting and -inhibiting effects on BC cells. In addition, TNF $\alpha$ modulates cancer cell proliferation through activating MAPK 1 and 2 and PI3K/AKT pathways and increases cancer cell sensitivity to chemotherapy and radiotherapy by driving cells out of the dormant G0/G1 phase of growth cycle (Correa et al. 2017).

Vascular endothelial growth factor (VEGF) is another well-studied angiogenic growth factor secreted largely by visceral adipose tissue (Fain et al. 2004) and expressed by various human cancers including BC (Goel \& Mercurio 2013). Increased IL-6 production by obese adipocytes increased in vivo VEGF abundance in TME and reduced therapeutic VEGF resistance in obese BC patients (Incio et al. 2018). This indicates close connection between VEGFmediated angiogenesis and obesity-associated inflammation to modulate favorable breast TME development.

Increased secretion and production of cytokines (IL-6, TNF $\alpha$ ) and PGE2 by tissues lead to increased transcription of the cytochrome P450 19 aromatase (CYP19) gene encoding aromatase (enzyme for accelerated estrogen synthesis by local adipose tissues). In addition, macrophages upregulate aromatase expression via specific mRNA sequences found only in breast tissue, making women with obesity more susceptible to estrogen receptorpositive (ER+) BC (Iyengar et al. 2013). This specific type of macrophage crowning is found in $75 \%$ of obese women, indicating inflammation as a mechanistic target linking obesity and ER+ BC (Iyengar et al. 2013).

Furthermore, obesity alters the immune responses against tumor cells. Excessive weight gain modifies the innate immune response, promoting cancer initiation, growth and development by reducing cytotoxicity of natural killer (NK) cells and antigen presentation by dendritic cells (DC) (Himbert et al. 2017). As multiple studies reported the role of inflammatory adipo-cytokines in TME formation and breast tumor progression especially under obese condition, dissecting their possible mechanism of action is critical in improving poor cancer outcomes in pre- and post-therapy. Below we summarized the functions of these major adipo-cytokines in BC progression (Fig. 1).

Higher levels of leptin secreted by obese adipocytes induce a pro-inflammatory, pro-angiogenic and promitogenic microenvironment (Newman \& GonzalezPerez 2014, Himbert et al. 2017, Picon-Ruiz et al. 2017). Furthermore, leptin is expressed in $75 \%$ of tumors and its receptor is expressed in $80 \%$ of tumors. Leptin receptor expression is dependent on ER expression and tumor size (Jarde et al. 2008). In vitro and in vivo studies have reported that leptin acts via extracellular signal-regulated kinase (ERK) activation and possibly by estrogen signaling (Dubois et al. 2014, Yuan et al. 2014). Hence, leptin plays an important role in mediating obesity-associated BC risk (Fig. 1). Leptin increases obesity-associated cancer by multiple pathways: (a) Synergistic interaction of leptin receptors with the IGF-1 receptor (IGF-1R) activates AKT and ERK, which are responsible for obesity-associated BC progression by EGFR transactivation and PI3K/AKT phosphorylation. Both, leptin and IGF-1 are potent mitogens and their interaction significantly increases proliferation, migration and invasion of BC cells (Saxena et al. 2008). (b) Leptin induces phosphorylation of insulin receptor substrate (IRS)- 1 and IRS-2, which in turn induces AKT activation. (c) Leptin upregulates MMPs, survivin and Notch1. This is in line with other studies where MMP inhibitor, GM6001, and survivin inhibitor, lovastatin, inhibit leptin and IGF-1-mediated EGFR transactivation respectively, in human and mice BC models. This inhibition is followed by reduction in invasiveness and migration of human BC cells (Greco et al. 2003, Escobar et al. 2004, Saxena et al. 2008, Knight et al. 2011)

Resistin is a cysteine-rich peptide hormone secreted by adipose tissue (Wang et al. 2002), and it can promote tumor progression by stimulating Toll-like receptor 4 (TLR4)/ NF-кB/STAT3 signaling pathway (Wang et al. 2017). Moreover, resistin produced by adipose macrophages have similar function as leptin, and high serum resistin levels are associated with increased in vivo breast cancer metastasis, tumorigenesis, and higher risk of BC progression especially in postmenopausal women (Wang et al. 2017) (Fig. 1).

Visfatin is an enzyme found in visceral adipose tissue and is also known as pre-B-cell colony-enhancing factor 1 (PBEF1) or nicotinamide phosphoribosyl transferase (Nampt) (Samal et al. 1994). Visfatin is particularly important in activating Notch1 signaling and inducing epithelial-mesenchymal transition (EMT), cell adhesion, as well as promoting BC cell growth, invasion, and metastasis (Dalamaga et al. 2011).

Endotrophin is collagen VI-soluble cleavage product secreted by adipocytes and has multiple roles like EMT stimulation, induction of tumor fibrosis, angiogenesis, and inflammation. However, the exact functions of adipocyte-secreted endotrophin in the obesity-BC association are yet unknown (Dalamaga et al. 2011, Lapeire et al. 2015). 


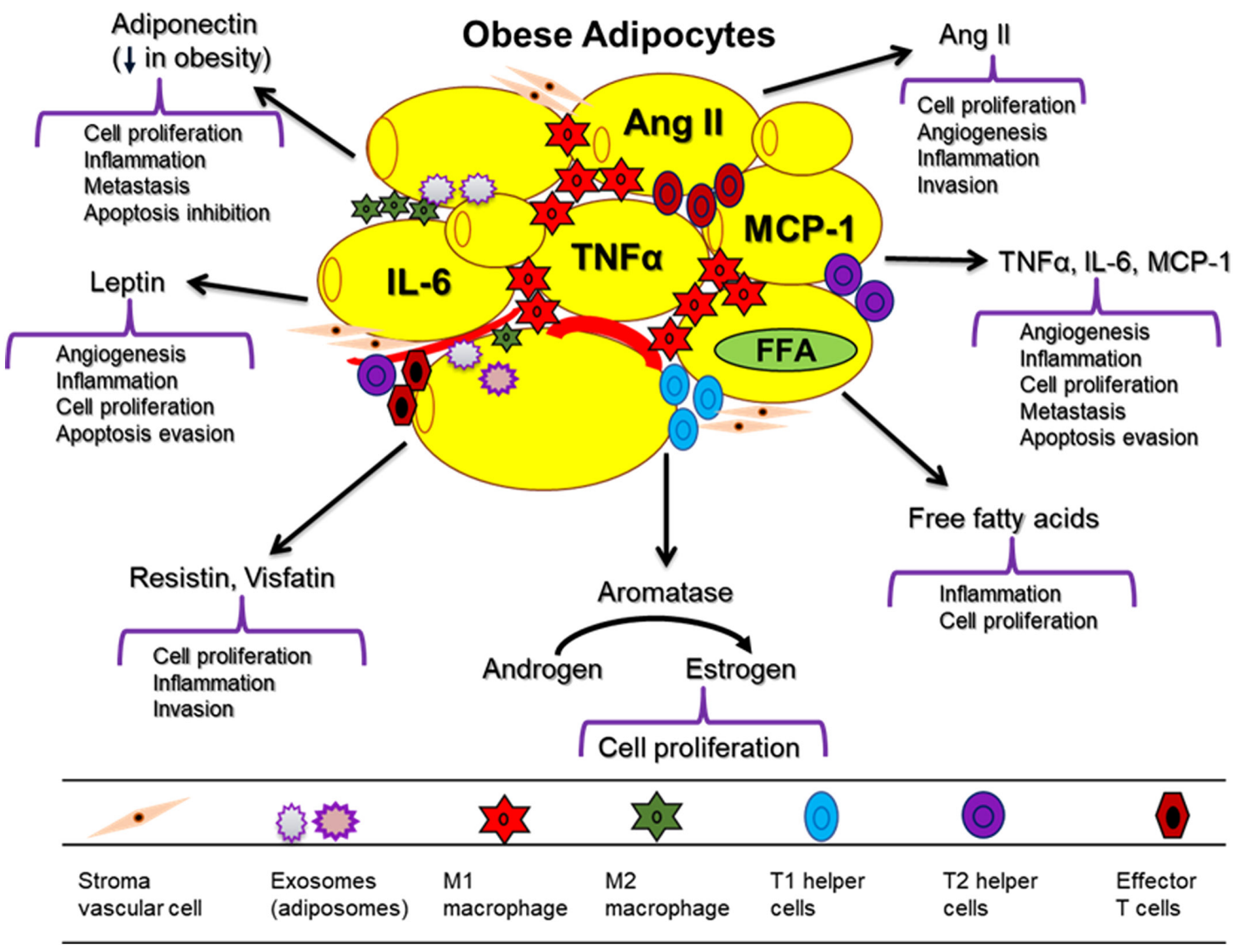

Figure 1

Altered adipose secretory functions contributes to obesity and breast cancer interaction by promoting the tumor microenvironment (TME). Obesity induces secretion of many pro-inflammatory and growth-promoting biomarkers by hypoxic obese adipocytes, which in turn, facilitates tumor cell proliferation, angiogenesis, inflammation and apoptosis evasion in TME. Alteration of immune cell profile such as, increased M1:M2 and T1:T2 ratios, further aids in this process. A full colour version of this figure is available at https://doi.org/10.1530/ERC-19-0314.

Adiponectin, another major adipokine, is a protein hormone and regulates glucose homeostasis and fatty acid oxidation in our body (Diez \& Iglesias 2003). Interestingly, adiponectin has an inverse association with BC risk (Himbert et al. 2017). In vitro studies have reported a protective effect of adiponectin against cancer cell proliferation and metastasis, possibly via stimulation of adenosine monophosphate-activated protein kinase (AMPK) and peroxisome proliferator-activated receptor $\alpha$ (PPAR $\alpha$ ) signaling and inhibition of MAPK pathway (Arditi et al. 2007, Himbert et al. 2017). In addition, adiponectin blocks VEGF, B-cell lymphoma (BCL)-2 (anti-apoptotic) expression, as well as increases Bcl2-associated X (BAX), caspase (pro-apoptotic) and the tumor cell-cycle arrest proteins (P53) expression (Divella et al. 2016). Adiponectin is responsible for switching macrophages from the M1 to M2 phenotype, thus improving the inflammatory profile (Li et al. 2011). By contrast, human BC cells express adiponectin receptors (AdipoR1, R2), which, when present at low concentrations can promote $\mathrm{ER}+\mathrm{BC}$ proliferation, but reduce triple-negative breast cancer cell (TNBC) growth in the presence of 17- $\beta$ estradiol (Dieudonne et al. 2006, Pfeiler et al. 2008, Austin et al. 2018). This can be explained by the downstream signaling crosstalk between adiponectin and estrogen receptors in modulating AMPK and MAPK pathways respectively in TNBC and ER+ BC cells (Gelsomino et al. 2019). However, these studies demonstrate the controversial role of adiponectin in breast cancer and a significant mechanistic research gap in identifying adiponectin and estrogen signaling modulation in obesity-BC crosstalk.

Obesity is often associated with insulin resistance, resulting in increased levels of insulin and IGF-1. IGF-1 is a growth factor derived from obese adipocytes and its action is mediated via IGF-1R which are often elevated or mutated in different cancers including BC (Picon-Ruiz et al. 2017). It is a potent mitogen which increases risk and mortality in obese individuals
C) 2019 Society for Endocrinology Published by Bioscientifica Ltd. Printed in Great Britain 
(Picon-Ruiz et al. 2017). Moreover, binding of insulin and IGF-1 to their respective receptors activates a series of events, including PI3K/AKT/mTOR signaling cascade, which in turn increases the expression of S6 kinases and inhibits eukaryotic translation initiation factor $4 \mathrm{e}$ (eIF4e) (Pollak et al. 2004). This further increases cellcycle progression proteins such as cyclin D1 and c-Myc, while reducing apoptosis via suppressed expression of Bax and enhanced expression of $\mathrm{Bcl} 2$ (Pollak et al. 2004). In addition, insulin and IGF-1 promote estrogen signaling along with aromatase activity, thereby promoting hormone-sensitive BC in individuals with obesity. Apart from this, insulin inhibits hepatic synthesis of sex hormone-binding globulin (SHBG), causing impaired sex hormone (testosterone, dihydrotestosterone, estradiol) binding and transportation. Altogether, it promotes ER+ BC under obese conditions (Iyengar et al. 2013).

Another important player is serum estradiol (a steroid hormone), the levels of which are increased in obesity, promoting development of $\mathrm{BC}$ will be discussed in detail in later sections of the review.

COX-2 is another major pro-inflammatory enzyme connecting obesity and $\mathrm{BC}$ via inflammation. COX-2 overexpression had been found in both invasive and non-invasive human breast carcinomas (Half et al. 2002) and COX-2-derived lipid mediator, PGE-2 is found to be positively correlated with obesity and breast inflammation in women (Wang \& Dubois 2012). PGE-2 can be secreted from obese adipose macrophages and found to have a role in aromatase upregulation through cAMP-PKA pathway in human breast tissue (Subbaramaiah et al. 2012). Moreover, previous studies from our lab and others have reported positive PGE-2 action on adipose lipogenesis, inflammation, and remodeling in obesity (Wortman et al. 2009, García-Alonso et al. 2016). Taken together, all these associations suggest COX-2 derived PGE- 2 role in BC progression by modulating obesity-associated inflammation.

In addition to the above-mentioned adipose-derived factors, browning of white adipose tissue (beige) and brown adipose tissue (BAT) plays a significant role in obesity and BC interactions. Increased uncoupling protein 1 (UCP1) protein and mRNA expression in late-stage and malignant breast tumors indicate higher mammary fat browning in cancer (Wang et al. 2014, Han et al. 2018). One possible explanation could be higher white adipose tissue (WAT) browning in hypermetabolic cancer patients to compensate for weight loss induced in cancer (Han et al. 2018). However, the dynamics of WAT browning in inducing weight loss and improving metabolic health versus increasing WAT atrophy in cancer cachexia needs further investigation to elucidate its conflicting roles in the obesity and $\mathrm{BC}$ connection.

The RAS is another major physiological system which has close connection with obesity and inflammation, through altered adipocytokine profiles and dysregulated metabolism (Fig. 1). Interestingly, both WAT and BAT express all the components of RAS including angiotensinogen and Ang-II. Furthermore, studies have reported that UCP-1 induction in response to cold exposure via activation of the sympathetic nervous system increases in vivo Ang II expression, which was inhibited upon administration of its receptor blocker, losartan (Pahlavani et al. 2017). Increased BAT expression in the mammary gland is specifically associated with upregulated levels of angiogenic, CD31 and metastatic, COX2 in vivo. By contrast, COX2 inhibition leads to reduced tumor growth along with reduced level of classic brown (UCP-1) and beige (MYF5) markers in mouse xenograft of MDA-MB-231 triple-negative breast cancer cell (Singh et al. 2016). Moreover, our lab reported COX-2-derived PGE-2 upregulation in response to timedependent Ang II administration in vitro suggesting Ang II role in connecting obesity and $\mathrm{BC}$ via COX-2 modulation (Kim et al. 2002).

Hence, dissecting the relationship between Ang II, adipose tissue types and $\mathrm{BC}$ presents an important area of future research as both Ang II and UCP-1-levels are found to be elevated in cancer, especially BC. In the next sections of this review, we will discuss the detailed function of RAS and its key bioactive hormone Ang II in the TME under obese conditions. As multiple studies have reported the importance and the role of adipose-derived factors like adipokines, cytokines, growth factors, hormones in development of obesity-associated BC - dissection of the underlying pathways is critical, in order for us to understand the mechanisms linking obesity to BC.

\section{Renin-angiotensin system (RAS) and its components}

RAS is a well-studied physiological system in our body that has potential to modulate both obesity and BC. It is classically known for its role in blood pressure and fluid balance regulation (Yvan-Charvet \& Quignard-Boulange 2011). Recently, it has been found to be expressed in various tissues including liver, kidney, heart, brain, and adrenal glands and have a local role (Yvan-Charvet \& QuignardBoulange 2011). RAS has key roles in inflammation, insulin resistance and obesity development (Engeli et al. 2000, Yvan-Charvet \& Quignard-Boulange 2011, https://erc bioscientifica com
C) 2019 Society for Endocrinology Published by Bioscientifica Ltd. Printed in Great Britain 
Kalupahana \& Moustaid-Moussa 2012). The common precursor of all RAS peptides is angiotensinogen (Agt), which is primarily secreted by the liver. However, under obese conditions, adipocytes secrete large amounts of Agt. Agt is cleaved by renin, an enzyme secreted from the kidneys, to form angiotensin I (Ang I). Ang I is further cleaved to angiotensin II (Ang II) by angiotensin-converting enzyme (ACE) produced in the lungs. Ang II is a major bioactive hormone in the RAS pathway and mediates its effect via binding to two receptors (AT1R, AT2R). AT1R stimulation results in blood pressure elevation, whereas AT2R lowers blood pressure. Ang I and Ang II are further cleaved into Ang (1-9) and Ang (1-7) (Fig. 2) which then binds to Mas receptor to promote vasodilation, growth and fibrosis inhibition (Ferrario et al. 2010). Ang II can be cleaved by aminopeptidases to produce Ang III and Ang IV, with Ang IV binding to a newly identified receptor, AT4 (not shown in Fig. 2). However, the exact function of AT4 has not yet been identified (Smith et al. 2016) and researchers have reported conflicting effects of Ang IV on vasculature as an antagonist (Slinker et al. 1999) and agonist of Ang II (Shostak \& Chariot 2015). In obesity, local RAS is activated, and it regulates both adiposity and inflammation (Ramalingam et al. 2017). Hence, it has a potential role in developing obesity-associated cancer. Evidence suggests that the combined effects of Ang II and its receptor AT1R significantly increase tumor angiogenesis especially in receptor-negative $\mathrm{BC}$ via increasing gene expression of angiogenic growth factors, such as VEGF and hypoxiainducible transcription factor $2 \alpha$ (HIF-2 $\alpha$ ) (Herr et al. 2008).
Meanwhile, Ang II production and/or expression is associated with improvements of breast cancer-related adverse outcomes (Oh et al. 2016, Raimondi et al. 2016). In addition to that, Ang II and AT1R interaction in obesity is responsible for increased macrophage polarization (shift from anti-inflammatory M2 to pro-inflammatory M1), infiltration and higher M1/M2 ratio which can be altered by ARB administration in vivo (Ma et al. 2011).

Genes for the RAS pathway (Agt, receptors, renin and ACE enzymes) are expressed in different cancers including BC cells. RAS inhibitors, such as ACE-I (e.g. captopril, enalapril) and/or AT1R blockers or ARBs (e.g. telmisartan, losartan), have been successfully used as antihypertensive agents to prevent pathologies associated with RAS overexpression in many in vitro, in vivo and clinical studies (de Kloet et al. 2011). Interestingly, RAS inhibitors have been used to prevent diabetes (Scheen 2004). Moreover, some of these inhibitors have been used to improve overall cancer survival depending on the cancer type and type of inhibitor used (Sun et al. 2017). Given the abovementioned associations, it is important to understand the potential mechanism of action of RAS in $\mathrm{BC}$, as well as the role of adipose tissue RAS in obesity and associated BC.

\section{Mechanism of RAS action promoting the tumor microenvironment}

Various RAS components are overexpressed in BC modulating cancer cell capacities of growth, proliferation,

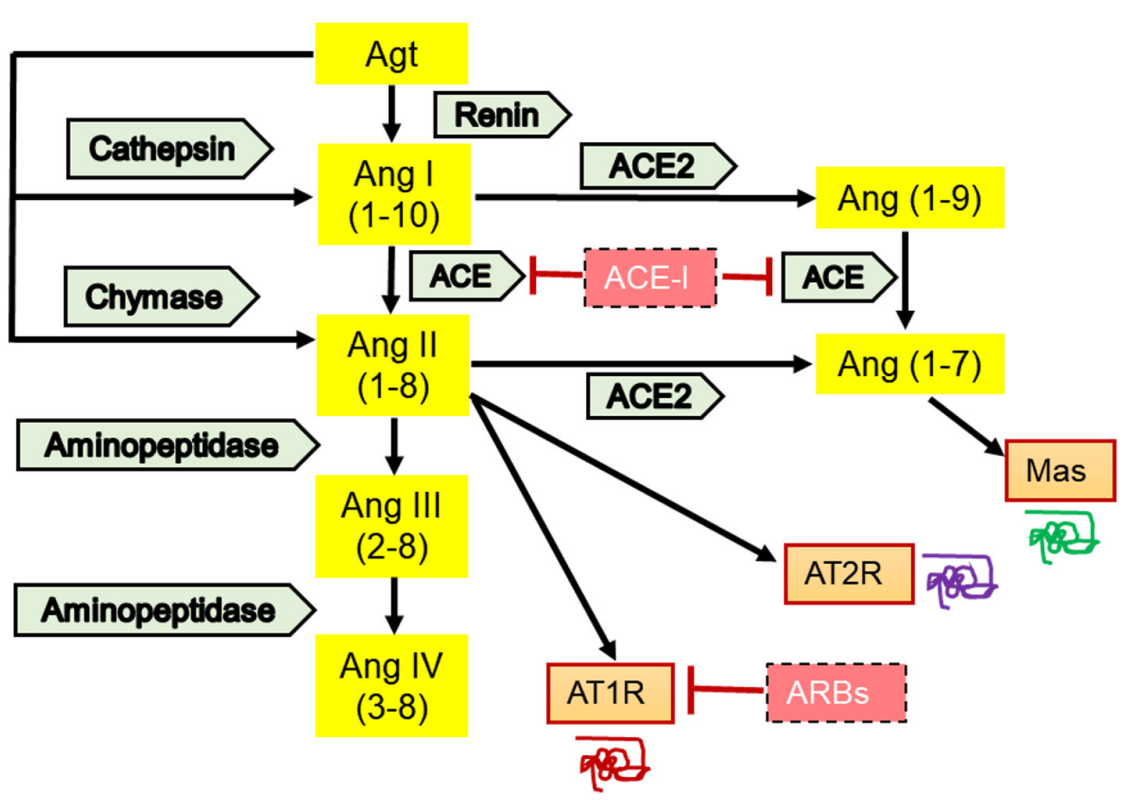

Figure 2

Components of the renin-angiotensin system. Classic RAS pathway initiates when the obligatory peptide precursor of all bioactive RAS components, angiotensinogen (Agt), is cleaved by two enzymes renin and angiotensin-converting enzyme (ACE) to produce angiotensin (Ang) I and Ang II, respectively. Ang II is the main bioactive of the system and exerts its effects via binding to two receptors Ang type I (AT1R) and type 2 (AT2R), promoting either vasoconstriction via AT1R or vasodilation via AT2R. Cathepsin and chymase can also produce Ang I and Ang II from Agt independent of the classic renin-ACE pathway. Ang I and Ang II can be further cleaved into Ang (1-9) and Ang (1-7) to exert their action via Mas receptor, which has functions similar to AT2R. Ang II is again cleaved into Ang III and Ang IV by the action of aminopeptidases. RAS blockade by ACE inhibitors (ACE-I), and AT1R and AT2R blockers (ARBs) is used as antihypertensive therapy and has protective effects against obesity and cancer. A full colour version of this figure is available at https://doi.org/10.1530/ERC-19-0314. 
Table 1 Expression of RAS components in human breast tissues and cancer cell lines.

\begin{tabular}{|c|c|c|}
\hline Model & $\begin{array}{l}\text { Overexpressed RAS } \\
\text { components }\end{array}$ & References \\
\hline $\begin{array}{l}\text { In vitro and } \\
\text { In vivo }\end{array}$ & AT1 receptors (AT1R) & (Rhodes et al. 2009) \\
\hline In vitro & Ang II, ACE, AT1R & (De Paepe et al. 2001) \\
\hline In vitro & $\begin{array}{l}\text { Agt, renin, Ang II, } \\
\text { ACE, AT1R }\end{array}$ & (Herr et al. 2008) \\
\hline In vitro & AT1R & (Muscella et al. 2002) \\
\hline In vitro & AT1R & (Inwang et al. 1997) \\
\hline In vitro & Agt, pro-renin, ACE, AT1R & (Tahmasebi et al. 2006) \\
\hline
\end{tabular}

and invasion as summarized in Table 1 . While increased AT1R expression is associated with increased pro-tumor functions in both BC and breast epithelial cells, AT2R antagonizes the pro-tumor activity of AT1R by blocking its downstream signaling during BC progression (George et al. 2010).

A recent large-scale study comprising 31 gene profiling and 3200 microarray experiments reported that AT1R is overexpressed in 10-20\% of BC cohorts especially in ER+, ErbB-2 (HER2)-negative BC and is responsive to estrogen and epidermal growth factor receptor (EGFR) signaling. The study also reported that AT1R and ErbB-2 overexpression were mutually exclusive because of their overlapping downstream pathways of ERK activation (Rhodes et al. 2009). Similarly, increased expression of AT1R and ACE has been found in metastatic ovarian adenocarcinoma and prostate cancer compared to benign cancers indicating they might be responsible for transition to invasive tumor in these cases (Suganuma et al. 2005, Uemura et al. 2006). AT1R overexpression is found in breast hyperplasia (higher irregular shaped breast cells), ductal in situ carcinoma (DISC), but were not observed in invasive cancers as the downstream growth-regulating pathways were no longer needed by the invasive carcinoma cells (Uemura et al. 2006, Rhodes et al. 2009). However, AT2R demonstrates inverse expression patterns to AT1R (i.e., higher AT2R expression was found in invasive BC). This phenomenon can be explained by correlation between AT2R and inducible nitric oxide synthase (iNOS) toward inhibiting vascularization and initiating apoptosis of invasive carcinoma cells. This occurs by inhibiting PI3K/AKT intracellular signal transduction and bypassing the EGFR growth signaling (De Paepe et al. 2002). Thus, these studies indicate the involvement of both AT1R and AT2R in the initial stages of cancer development and invasiveness, respectively (George et al. 2010).

Another mechanism of AT1R activation includes AT1R interaction with NADPH oxidase to facilitate inflammation and angiogenesis, leading to potential TME restructuring. Other RAS-mediated malignant transformation mechanisms involve processes like cell proliferation due to higher sensitivity to growthstimulating signals and lowered or insensitivity to growth inhibitory signals, angiogenesis, alteration of apoptosis, increased invasive, metastatic and tissue replicative capacities, and inflammation (Deshayes \& Nahmias 2005, Floor et al. 2012). These potential mechanisms of RAS action are briefly discussed below.

\section{Cell proliferation and angiogenesis}

AT1R is highly overexpressed in TAMs, facilitating macrophage infiltration and VEGF production in vivo, thereby promoting inflammation-mediated angiogenic tumor development (Egami et al. 2003). EGFR (RTK) transactivation via AT1R induces matrix metalloproteinase (MMP) secretion followed by activation of PI3K/AKT signaling cascade (Deshayes \& Nahmias 2005). Additionally, AT1R mediates its proangiogenic effect by increasing both VEGF and VEGF receptor 2 (VEGFR2) expression in endothelial cells, followed by increased expression of angiopoietin-2, a major regulator of angiogenesis via EGFR binding. Similar effects were observed in microvascular endothelial cells. This was confirmed in AT1R-knockout mice, which had reduced tumor growth and angiogenesis compared to wildtype controls (Egami et al. 2003). Moreover, treatments with AT1R antagonists reduced tumor size confirming the role of AT1R in cancer progression (Egami et al. 2003). In contrast, AT2R inhibits autophosphorylation of EGFR by inducing Src homology region 2 domain, containing tyrosine phosphatase-1 (SHP-1), a tumorsuppressor gene. SHP-1 renders its anti-proliferative effect by inhibiting STAT3 phosphorylation (Song et al. 2017) and girdin-dependent tyrosine phosphorylation in PI3K/AKT signaling (Mittal et al. 2011). EGFR-induced cell proliferation can be antagonized by AT2R-interacting protein ATIP (another putative tumor suppressor) via increased AT2R transport to cell membrane (Nouet et al. 2004). AT2R inhibits AKT and endothelial nitric oxide synthase (e-NOS) phosphorylation and activation by blocking VEGFR2 expression. Thus, AT2R can reduce cell migration and tube formation in human endothelial cells (Deshayes \& Nahmias 2005). Furthermore, AT2Rknockout mice had faster growth of stromal cells and increased VEGF production in a murine pancreatic cancer model (Doi et al. 2010). Similarly, Mas receptor activation significantly reduced lung tumor growth and 
vessel density, along with decreased VEGF expression in an in vitro human lung carcinoma model, possibly by blocking ERK signaling (Gallagher \& Tallant 2004). This summarizes the possible opposite roles of AT1R and AT2R in tumor cell proliferation, suggesting that antagonist and agonists of the respective receptors might be associated with beneficial anti-tumor outcomes.

\section{Apoptosis}

Ang II-mediated AT1R activation increases cell survival and inhibits apoptosis during malignant cell formation in two ways: (i) NF-kB activation which activates Bcl-XL and survivin, which then leads to cisplatin (alkylating agent)-induced apoptosis inhibition in pancreatic cancer cells (Amaya et al. 2004). (ii) PI3K/AKT signaling activation is followed by downregulation of caspase 9, resulting in doxorubicin (topoisomerase inhibitor)-induced apoptotic inhibition in ER+ BC cells (Zhao et al. 2008). AT1R increases survivin expression and suppresses caspase-3-mediated apoptotic activity by PI3K/AKT pathway, which in turn, promotes survival in microvascular endothelial cells in breast tumor microenvironment. Furthermore, activation of PI3K/AKT and Ras/MAPK/ERK signaling pathways are often associated with downregulation of STAT signaling and upregulation of survivin and Bcl-2 expression in BC cells (Aziz \& Aziz 2013). In contrast, AT2R overexpression induces apoptotic cell death in prostate and lung cancer cells independent of Ang II stimulation, but dependent upon p38 MAPK and caspases 3 and 8 levels, although the exact mechanism of action of AT2R mediated apoptosis in different cancer cell types needs further investigation (George et al. 2010, Pickel et al. 2010, Pei et al. 2017). All these studies indicate potential anti-apoptotic role of AT1R in obesity-BC crosstalk, while the apoptotic role of AT2R in cancer progression is controversial and needs further investigation.

\section{Inflammation}

RAS signaling activation through AT1R promotes downstream activation of several transcription factors like NF- $\mathrm{kB}$, STAT 3 and hypoxia-inducible transcription factor $1 \alpha$ (HIF-1 $\alpha)$, followed by induction of various molecules integral to TME (i.e. IL-6, IL-8, MCP-1, macrophage colony stimulating factor (M-CSF), VEGF, tissue inhibitor of metalloproteinase 1 (TIMP1), HIF- $1 \alpha$, and HIF- $2 \alpha$ ) (Van Uden et al. 2008, George et al. 2010). In contrast, AT2R inhibits MCP-1 production in smooth muscle cells by stabilizing IKB $\alpha$ via SHP-1 (Deshayes \& Nahmias 2005). Apart from this, another key inflammatory molecule generated by RAS is reactive oxygen species (ROS) through AT1R and NADPH oxidase interaction, followed by activation of the MAPK and PI3K/AKT signaling pathways. Hypoxia, excess ROS generation, and oxidative stress result in increased endoplasmic reticulum stress, cell damage or death; which in turn activates several downstream stress recovery pathways (autophagy, anti-inflammatory) and increases growth factor signaling in TME (Gallagher \& Tallant 2004). Uemura et al. found that Ang II induces ROS production in prostate cancer cells, while AT1R inhibition reduces oxidative stress and free radical production in an in vitro model of prostate cancer (Uemura et al. 2008). In addition, Ang II/AT1R signaling promotes production and infiltration of TAMs in different tumor models, while RAS inhibitors can restrain tumor growth and TAM response (Pinter \& Jain 2017). By contrast, AT2R and its interacting intracellular protein, ATIP, display tumor-suppressor effect (Rodrigues-Ferreira et al. 2015). AT2R and its agonists have protective anti-inflammatory effect against obesity and other chronic diseases such as hypertension, cardiac and renal inflammation (Esquitino et al. 2015); however, the mechanisms behind its inflammatory role in different cancers need more research. Interestingly, AT2R is overexpressed in different BC subtypes (RodriguesFerreira \& Nahmias 2015) and researchers developed novel human invasive in vitro $\mathrm{BC}$ model to study the AT2R-ATIP interaction independent of AT1R-Ang II activation (Rodrigues-Ferreira et al. 2012). However, AT2R-ATIP interaction promoting or preventing in BC needs further illustration given anti-proliferative and antimetastatic effect of ATIP in different in vitro and in vivo cancer models (Guimond et al. 2013, Rodrigues-Ferreira $\&$ Nahmias 2015). This suggests RAS role in promoting cancer-related inflammation in an immunosuppressive microenvironment which could be a possible mechanism of action for BC progression in obesity by adipose Ang II overproduction.

\section{Cell migration, invasion, and metastasis}

Accumulating evidence shows that RAS enhances the ability of malignant cells to migrate, invade, and metastasize as well as facilitate TME (George et al. 2010). AT1R plays an important role in leukocyte extravasation by increasing expression of endothelial adhesion molecules like E-selectin, P-selectin and vascular cell adhesion molecule-1 (VCAM-1), inducing malignant cell growth, neovascular formation and metastasis (Alvarez et al. 2004).
C) 2019 Society for Endocrinology Published by Bioscientifica Ltd. Printed in Great Britain 
Furthermore, Ang II-AT1R-mediated activation of PI3K pathway induces invasion and migration of choriocarcinoma (Ishimatsu et al. 2006). Interestingly, one contrasting result was found in BC cells treated with Ang II. Barker et al. reported that AT1R activation resulted in reduced cell adhesion and invasion in receptor-positive MCF-7 and T47D BC cells, through protein kinase C (PKC)-dependent downregulation of integrin receptor

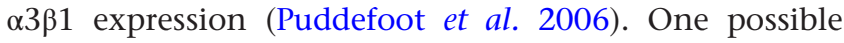
explanation could be the competitive action of integrins to activate ERK1/2 via the FAK-SRC-MAPK pathway instead of the Ang II-mediated EGFR phosphorylation pathway. However, other studies reported activation of the epithelial basement membrane receptor, integrin $\alpha 3 \beta 1$, which leads to higher induction of MMP-9 and COX-2 in different cell and animal models of BC (Subbaram \& Dipersio 2011). Therefore, these contrasting studies suggest the need of further research involving different tumor subtypes under different conditions to dissect the role of Ang II in BC cell migration.

Apart from the aforementioned regulatory functions of RAS, mutations or polymorphisms of RAS components have a significant effect on cancer development and risk modulation. Higher AT1R expression is found in invasive carcinomas (such as ovarian adenocarcinoma) than benign cystadenomas (Suganuma et al. 2005). Moreover, AT1R and ACE expression is localized to the tumor in gastric cancer and tumor metastatic ability was influenced by an ACE insertion/deletion (I/D) polymorphism (Röcken et al. 2005). ACE-I/D polymorphism and AGTR1 mutation at 5' end are associated with reduced postmenopausal $\mathrm{BC}$ risk (George et al. 2010). Hence, modulation of RAS components expression in cancer, particularly $\mathrm{BC}$, is a potential therapeutic approach and novel treatment option which requires further investigation.

\section{Potential mechanisms linking angiotensin with obesity-associated BC}

Increased Ang II produced by local adipocytes in breast could be a potential link between obesity and BC. Here, we are proposing several mechanisms which involve modulating multiple factors such as estrogen, growth factor receptors, oxidative stress and inflammation (Simone et al. 2016) associated with obesity and BC with or without RAS implication.

\section{Estrogen signaling}

Ovaries are the primary producers of estrogen in premenopausal women, while after menopause, adipose tissue including that of breast produces estrogen. High aromatase expression in obese fat cells is a source of high estrogen levels in postmenopausal BC (Simpson \& Brown 2013). Estrogen alone or in combination with epidermal growth factor (EGF) induces Ang II-AT1R signaling. This leads to downstream activation of MAPK/RAF/ERK1/ERK2 mediated cell proliferation and survival in both ER-positive and ER-negative human BC cells (Lim et al. 2006). In addition, Ang II receptor (AT1R and AT2R) signaling can be modulated by ER expression. For instance, decreased AT1R and increased AT2R expression have been observed in hearts of ovariectomized and/or estrogen-replaced mice to improve responses to ischemia and reperfusion injury (Xue et al. 2015). Furthermore, estrogen signaling and its activity are strongly influenced by obesity-associated inflammatory markers (Zahid et al. 2016). There are three types of receptors involved in estrogen signaling, $\mathrm{ER} \alpha$, ER $\beta$ and $G$ protein-coupled estrogen receptor (GPER). $\mathrm{ER} \alpha$ is found to regulate RAS components transcription in an in vivo hypertensive model (Tremblay et al. 2010), hence, may be associated with other metabolic alterations mediated by RAS pathway. Further, GPER is expressed in all types of breast carcinomas and its deregulated expression is associated with poor cancer outcomes, tumorigenesis and tamoxifen resistance (Catalano et al. 2014, Yan et al. 2015). GPER exhibits functional and structural properties of G protein-coupled-receptor (GPCR) superfamily members and studies have shown that it plays a role in estrogen-induced carcinogenesis (Simone et al. 2016). In addition, both AT1R and GPER are GPCRs and hence might follow a similar pathway to EGFR phosphorylation to induce cancer cell proliferation and mediate an obesity-BC interaction. Estradiol action via GPER signaling promotes protein kinase A (PKA)-dependent cell proliferation, by activation of ERK1/ERK2 and PI3K/ AKT pathway. Moreover, GPER is responsible for epithelial cells loss of polarity and cell adhesion properties, followed by mesenchymal stem cell-like adaptations for enhanced metastatic and invasive properties. This ultimately leads to progression of estrogen-induced carcinogenesis and increased MMP-9 expression in the EMT process. Within the TME, GPER can promote new vascular tube formation and inflammation through activation of HIF-1 $\alpha$, PGE2 and IL-6 expression (Samarajeewa et al. 2013, Che et al. 2014), which are potential targets of Ang II-mediated inflammation and angiogenesis in obesity-associated BC. In lieu, Ang II is a potential agonist of GPCR and known to induce EGFR transactivation (Forrester et al. 2016). Based on these findings, it is likely that Ang II is a potential modulator of estrogen signaling via GPER in 


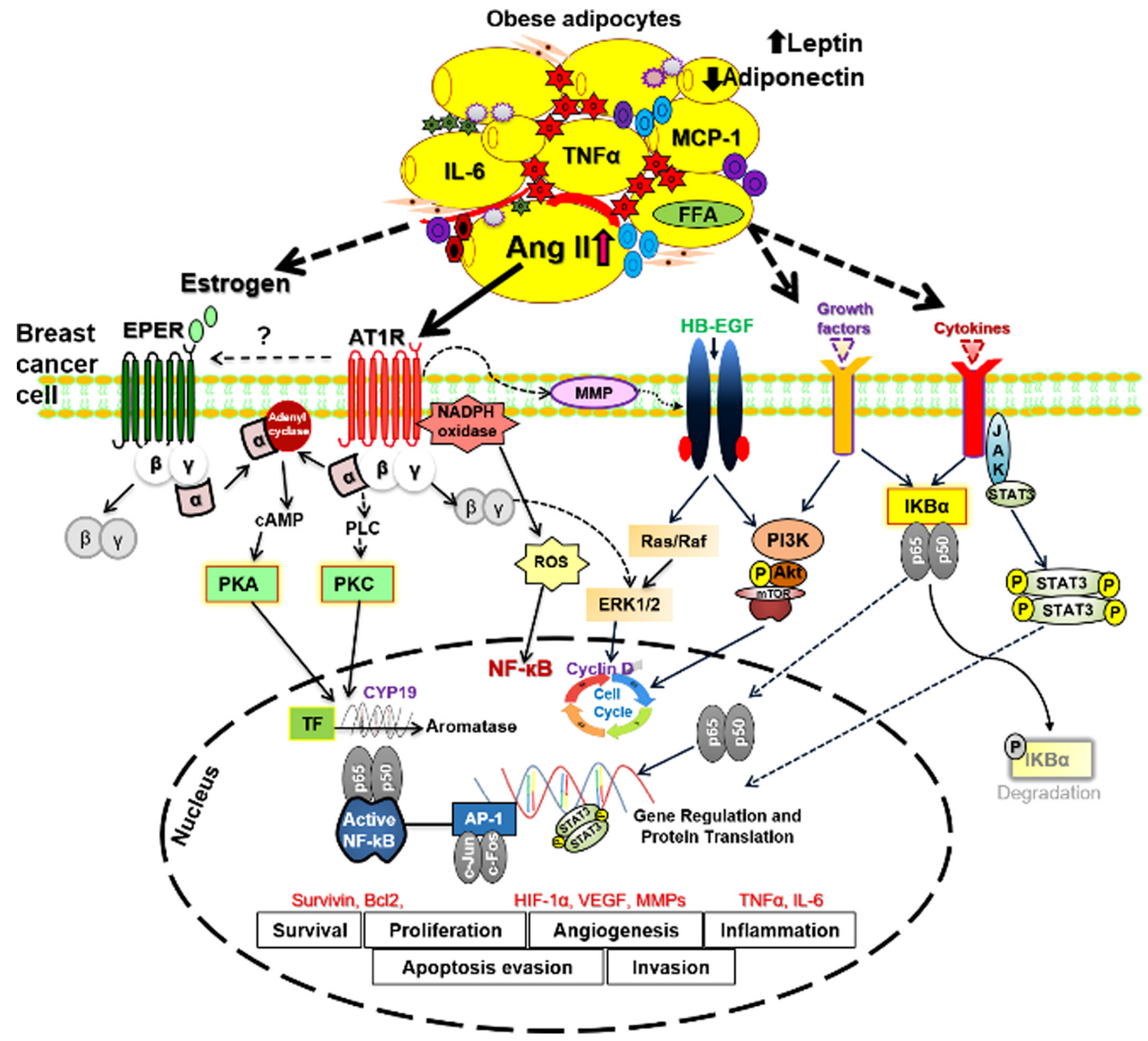

Figure 3

Obesity and breast cancer crosstalk by Ang II and AT1R interaction. In obesity, hypertrophic and hypoxic adipocyte secretes many pro-inflammatory cytokines, adipokines, hormones and growth factors like TNF $\alpha$, MCP-1, IL-6 and Ang II. Moreover, increased leptin and reduced adiponectin secretion can deteriorate the pro-inflammatory microenvironment. Hence, local adipose RAS is activated and promotes tumor microenvironment (TME) by Ang II-AT1R interaction (classic). AT1R-dependent cleavage of heparin-bound extracellular growth factor (HB-EGF) leads to transactivation EGF receptor (EGFR) and activation of ERK1/ERK2 and PKC. Then, activated EGFR can induce PI3K/AKT pathway and increased protein transcription facilitating cancer cell survival and proliferation (cyclinD1). Obese adipocyte-derived cytokines and growth factors also promote PI3K-AKT pathway, as well as NF-kB pathway via IKK degradation and STAT-3 phosphorylation. Generation of reactive oxygen species (ROS) by AT1R-NADPH oxidase interaction further promotes NF-KB pathway. Obese adipocyte-derived estrogen can bind to its receptor GPER on breast cancer cell and thus increases aromatase expression via transcription factor (TF) regulation by PKA and PKC signaling. However, the effect of Ang II-AT1R on GPER activation in breast cancer requires further illustration. Altogether, obese adipocyte-derived Ang II can promote breast cancer cell survival, proliferation, inflammation, angiogenesis, and invasion by upregulating expression of various pro-tumorigenic genes and proteins through EGFR transactivation and NF-kB inflammation. A full colour version of this figure is available at https://doi.org/10.1530/ERC-19-0314.

obesity-associated BC. However, further investigation is required to identify the role of Ang II in ER signaling during obesity and BC development (Fig. 3).

\section{Altered growth factor receptor signaling}

Two major metabolic pathways (PI3K/AKT and JUN/MAPK) arealtered in BC. These alterations promotecell proliferation and inhibit cell differentiation or cell-cycle arrest at beginning of tumor initiation. Therefore, tumorinitiating cells are protected from ROS and oxidative stress by switching to PI3K/AKT pathway. This in turn drives increased tumor progression and metastasis (Guille et al. 2013). By contrast, obesity is often associated with increased oxidative stress and ROS production which can lead to genetic instability inducing tumor progression by triggering the PI3K/AKT pathway (Seibold et al. 2011).
(C) 2019 Society for Endocrinology Published by Bioscientifica Ltd. Printed in Great Britain 
This may be explained by the presence of mutated oxidative stress-related genes in BC (Seibold et al. 2011), increased activation of autophagy regulatory pathways such as mTOR/HIF- $1 \alpha / \mathrm{NF}-\kappa \mathrm{B}$, inactivation of tumor suppressors such as PTEN and carcinogenic metabolicphenotypic changes induced by senescent fibroblasts to maintain BC cell growth (Jezierska-Drutel et al. 2013). In accordance, PI3Ks are important for cancer progression and can be activated in response to EGFR and GPCR interactions. PI3K receives signals from various growth factors and cytokines and converts them into intracellular messengers by generating phospholipids. This in turn leads to the activation of Akt and other downstream effector pathways (e.g. NF-кB) (Cantley 2002). Furthermore, Ang II-mediated EGFR transactivation is responsible for regulating various downstream signaling pathways such as PI3K/Akt, Ras/Raf/MAPK/ERK, STAT and PKC signaling (Aziz \& Aziz 2013, George et al. 2013). Aberrant overexpression or mutations of upstream growth factor receptors due to obesity/cancer/agonist (e.g. Ang II) action can cause amplification of EGFR and activation of small GTPase, ras proteins. For example, CSF-1 (colonystimulating factor-1), which is the upstream receptor of PI3K/Akt is expressed in $\sim 15 \%$ of BC tissues, but not in normal breast tissue (Kacinski 1995, Aziz \& Aziz 2013).

Leptin is a potent growth factor of $\mathrm{BC}$ and its receptors are expressed in both normal and cancerous breast tissues (Somasundar et al. 2004). Ang II is responsible for increased leptin synthesis in both in vitro (Skurk et al. 2005) and in vivo (Cassis et al. 2004) models of obesity and thus can be correlated with leptin-mediated BC progression. However, the detailed mechanism behind leptin and Ang II interaction in obesity-associated cancer crosstalk remains unclear.

Hence, mitogenic effect of Ang II in obesity-induced BC can be mediated by AT1R-dependent activation of EGFR (ERK) and protein kinases resulting in the upregulation of downstream activators such as AKT, MMP and other growth promoters (Escobar et al. 2004).

\section{Activation of the NF-кB inflammatory pathway}

Evidence suggests that Ang II is required for activation of

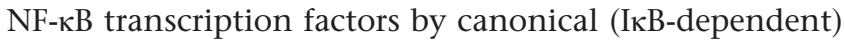
or non-canonical (IкB-independent) pathways (Zhang et al. 2005). Ang II activates NF-кB via NADPH oxidase and AT1R interactions followed by ROS generation. Therefore, NF- $\mathrm{kB}$ signaling cascade is a major downstream target by which obesity and $\mathrm{BC}$ could crosstalk via modulation of RAS signaling molecules (Fig. 3). However, mechanisms by which Ang II activates NF- $\kappa$ B requires further clarification. One more possible way to activate NF- $\kappa \mathrm{B}$ is through AT1R. It activates a series of molecular targets including PKC, EGFR, RTK, ERK1/2 or p38 MAP kinases which leads to the recruitment of adaptor proteins to IKK complex followed by $\mathrm{I} \kappa \mathrm{B}$ phosphorylation and degradation thereby activating NF-кB (Li \& Zhuo 2008). Similarly, Ang II induces phosphorylation of the p65 subunit of NF-кB, activating an alternative RAS/ERK1/2 signaling cascade and ribosomal S6 kinase (S6K), a downstream effector (Zhang et al. 2005). Both canonical and non-canonical pathways mediated via Ang II can induce NF- $\kappa$ B activation.

In cancer development and progression, NF- $\mathrm{B}$ promotes tumor initiation, proliferation, apoptosis inhibition, angiogenesis, chemoresistance, and metastasis (Wu \& Kral 2005). Furthermore, growth factors promote NF- $\kappa$ B activation through ErbB family stimulation. Studies have shown that EGF triggers NF- $\mathrm{B}$ activation in an IKKdependent manner (IкB degradation) in BC cells (Biswas et al. 2000). On the other hand, NF-кB and EGFR crosstalk promotes cancer progression by blocking EGFR inhibitors. $\mathrm{TNF} \alpha$ produced by TAMs activates NF- $\mathrm{B}$ in glioblastoma cells and provides resistance against EGFR inhibitors. TAMs sense dying cells through TLRs and activate NF- $\mathrm{B}$ and ERK1/2 signaling cascade, which in turn establishes a positive loop of NF- $\mathrm{B}$ activation by promoting the expression of pro-inflammatory cytokines like TNF $\alpha$ (Shostak \& Chariot 2015). These results indicate NF- $\mathrm{B}$ as a possible middle link in Ang II-induced, inflammationmediated, obesity and BC crosstalk.

\section{The role of RAS inhibitors in BC treatment}

RAS inhibitors (ACE-I) and AT1R blockers (ARBs) are clinically used as antihypertensive drugs without any major side effects. They are currently under evaluation for safety in cancer patients including BC (Rodrigues-Ferreira $\&$ Nahmias 2015). Some common antihypertensives such as ACE-I, which include captopril, enalapril, lisinopril and so forth, and ARBs, which include telmisartan, losartan, candesartan and so forth, are often used in combination to achieve a maximal effect (Komine et al. 2002). A recent in vitro study found that RAS inhibitors do not alter the cytotoxic effect of chemotherapeutic agents. Rather, their efficacy is enhanced when used in combination with chemotherapeutic BC drugs (Smith et al. 2016). Corroborating with this, multiple studies have reported that Ang II has detrimental effects on breast tumor outcomes such as angiogenesis and survival 
Table 2 Summary of studies reviewing the role of ACE-I/ARBs on different models of breast cancer research.

\begin{tabular}{l} 
Study \\
\hline Antihypertensive drug use and \\
breast cancer risk: A meta- \\
analysis of observational \\
studies \\
Use of beta-blockers, \\
angiotensin-converting \\
enzyme inhibitors and \\
angiotensin receptor blockers \\
and breast cancer survival: \\
Systematic review and \\
meta-analysis \\
The association between \\
angiotensin receptor blocker \\
use and breast cancer \\
characteristics \\
Antihypertensive medication \\
use and incident breast cancer \\
in women \\
Drugs affecting the renin- \\
angiotensin system and \\
survival from cancer: a \\
population-based study of \\
breast, colorectal and prostate \\
cancer patient \\
cohorts \\
Use of ACE inhibitors and \\
angiotensin receptor blockers \\
and primary breast cancer \\
outcomes \\
Protective effect of Perindopril \\
on tumor progression and \\
angiogenesis in animal model \\
of breast cancer \\
\end{tabular}

ARBs

Antihypertensive medication use including ACE-I

ACE-I and/or ARB

Human: observational case-control study

Human: a retrospective cohort study

Human: Longitudinal cohort

ACE-I and ARB

Human

ACE-I (Perindopril: $2 \mathrm{mg} / \mathrm{kg} /$ day)

In vivo:

BALB/c mice implanted with MDA-MB-231 breast cancer cells to generate mouse xenograft model and $60 \mathrm{mg} / \mathrm{kg}$ DMBA administered orally to induce breast cancer

The role of captopril and losartan in prevention and regression of tamoxifen -induced resistance of breast cancer cell line MCF7

Angiotensin II type 1 receptor antagonists inhibit cell proliferation and angiogenesis in breast cancer
ACE-I (captopril) and In vitro:

the combination of MCF-7 breast cancer cell ACE-I and ARB line (captopril plus losartan)

Ang II doses:

(1 to $10,000 \mathrm{nmol} / \mathrm{L}$ ),

ARBs: Losartan $(0.01,0.1,10,100$ micro $\mathrm{mol} / \mathrm{L})$,

In vivo dose:

Candesartan (5 or $10 \mathrm{mg} / \mathrm{kg}$ body weight) In vitro:

Ang II promoted cell

MCF-7 and MDA-MB-231 proliferation in MCF-7 In vivo:

BALB/c Female nude mice injected with AT1R over-expressing breast cancer cells Ang II effect on MCF-7

\author{
Major findings \\ Significantly reduced breast \\ cancer risk $(R R=0.80)$ with \\ 10 years or more ACE-I/ \\ ARB use \\ No association with ACE-I or \\ ARB use with overall \\ breast cancer survival
}

Higher incidence of invasive lobular breast carcinoma $(P=0.009)$ and worse cancer-specific survival $(P=0.024)$

ACE-I lower breast cancer risk in a subpopulation with long-term consistent use compared to never users

No association observed between breast cancerspecific mortality and ACE-I/ARB use

No difference in survival outcomes while ARB use improved relapse-free survival (RFS)

Significant reduction in angiogenic, VEGF and inflammatory, c-reactive protein (CRP) levels, followed by increased anti-oxidant parameters (GSH, SOD) found in diseased animal with ACE-I treatment compared to diseased control group; significantly reduced tumor growth found in mouse xenograft model due to ACE-I treatment Combination therapy with captopril and losartan with tamoxifen significantly prevented drug resistance of MCF-7 cells

proliferation in MCF-7 Losartan reduced adverse Candesartan significantly inhibited tumor growth and angiogenesis in mice xenograft model
(Cardwell et al.

(Namazi et al. 2014)

(Chen et al. 2013)
(Goldvaser et al. 2016)

(Devore et al. 2015) 2014)

(Chae et al. 2013)

(Patel and Nakka, 2017)

\author{
References \\ Raimondi et al. \\ 2016)
}

Nakka, 2017)


Table 2 Continued.

\begin{tabular}{|c|c|c|}
\hline Study & Treatment & Model \\
\hline $\begin{array}{l}\text { Inhibition of the renin- } \\
\text { angiotensin system } \\
\text { downregulates tissue factor } \\
\text { and vascular endothelial } \\
\text { growth factor (VEGF) in human } \\
\text { breast carcinoma cells }\end{array}$ & $\begin{array}{l}\text { ACE-I (Captopril, } \\
\text { Enalapril } \\
10 \text { ug/mL), and } \\
\text { ARB (Losartan, } \\
10 \text { ug/mL) }\end{array}$ & $\begin{array}{l}\text { In vitro: } \\
\text { MDA-MB-231 and } \\
\text { MCF-7 }\end{array}$ \\
\hline $\begin{array}{l}\text { Angiotensin II receptor type } 1 \\
\text { blockers suppress the cell } \\
\text { proliferation effects of } \\
\text { angiotensin II in breast cancer } \\
\text { cells by inhibiting AT1R } \\
\text { signaling }\end{array}$ & $\begin{array}{l}\text { AT1R blocker, } \\
\text { irbesartan }\end{array}$ & $\begin{array}{l}\text { In vitro: } \\
\text { MCF-7 }\end{array}$ \\
\hline
\end{tabular}

\begin{tabular}{|c|c|}
\hline Major findings & References \\
\hline $\begin{array}{l}\text { Blockade of RAS by ACE } \\
\text { inhibitors and AT1R } \\
\text { blocker inhibited } \\
\text { angiogenic VEGF } \\
\text { expression in highly } \\
\text { metastatic MDA-MB-231 } \\
\text { breast cancer cell line }\end{array}$ & $\begin{array}{l}\text { (Napoleone et al. } \\
\text { 2012) }\end{array}$ \\
\hline $\begin{array}{l}\text { AT1R blockade inhibited } \\
\text { Ang Il effects on cell } \\
\text { proliferation, cell-cycle } \\
\text { development as well as } \\
\text { downstream AT1R } \\
\text { signaling events, including } \\
\text { activation of MAPK and } \\
\text { NF-kB pathway }\end{array}$ & (Du et al. 2012) \\
\hline
\end{tabular}

(Tahmasebi et al. 2006, Herr et al. 2008, Xi et al. 2011, Oh et al. 2016). Additionally, blockade of RAS signaling contributes to the improvement of those adverse effects (Namazi et al. 2014, Raimondi et al. 2016, Smith et al. 2016) (Table 2). Another study reported that mice treated with the ACE-I (captopril) followed by radiation in induced mammary carcinoma had suppressed tumorigenesis than mice treated with either captopril or irradiation compared to control (Cho et al. 2016). Similar chemopreventive effects of ACE-I are found in combination with branchedchain amino acid in an in vivo model of hepatocellular carcinoma, along with suppressed VEGF-mediated neovascularization as confirmed by in vivo and in vitro studies (Yoshiji et al. 2010). However, more detailed research is warranted to assess the protective effects of RAS inhibitors in BC prevention.

\section{In vitro and in vivo studies investigating the protective role of ACE-I/ARBS}

ACE-I, captopril has anti-tumor and anti-angiogenic activity by inhibiting MMP-2 and MMP-9, which are responsible for matrix degradation and cell invasion, in a mouse model for Lewis lung cell carcinoma (Prontera et al. 1999). Furthermore, the sulfhydryl group in captopril is capable of chelating zinc ions, further reducing MMP activity. This was shown in a study where captopril administration resulted in reduction of tumor size in a mouse xenograft model of human renal carcinoma (Hii et al. 1998). Another study investigated the effect of ACE-I, perindopril on tumor progression and angiogenesis in a mouse xenograft model of triple negative BC. Patel et al. found that perindopril when treated with $2 \mathrm{mg} / \mathrm{kg}$ body weight per day significantly reduced tumor volume and VEGF levels, demonstrating a protective anti-inflammatory and anti-proliferative effect on TNBC (Patel \& Nakka 2017). Captopril was found to be cytotoxic to ER/PR negative human mammary ductal carcinoma cell line in the presence of copper salts (Small et al. 1999). Furthermore, ARBs were associated with downregulating cancer cell proliferation, angiogenesis and inflammation by inhibiting transactivation of ERK1/ERK2, VEGF and NK-кB (Deshayes \& Nahmias 2005). Kurosaka et al. reported that male AT1R knockout mice injected with Lewis lung cancer cells have delayed wound healing and angiogenic response (Kurosaka et al. 2009). This is consistent with other studies showing reduced AT1R expression on cell surface and in the cytoplasm of breast carcinoma cells upon AT1R knockout (Inwang et al. 1997, Tahmasebi et al. 2006). Corroborating with the previous results, overexpression of AT1R increased tumor growth and angiogenesis in a mouse xenograft model of ER+ BC. As expected, losartan (ARB) reversed tumor-promoting effects in both in vitro and in vivo model of $\mathrm{BC}$ (Oh et al. 2016). Similar results were found with ARB, candesartan using a nude mouse model of mammary carcinoma (Chen et al. 2013). Researchers also observed that in MCF-7 BC cells, captopril along with losartan reduced resistance to tamoxifen, both individually and in combination (Namazi et al. 2014). Additionally, losartan and captopril are associated with around $35 \%$ reduction of tissue factor, TF (metastatic potential) mRNA expression in metastatic MDA-MB-231 BC cells accompanied by a significant reduction in VEGF-associated neovascularization (Napoleone et al. 2012). In summary, Ang II has potential carcinogenic effect, especially when activated in breast adipocytes and mediates most of its inflammatory, angiogenic and tumor-promoting activities via binding to AT1R receptor. Therefore, inhibiting Ang II production and Ang II interaction with AT1R using ACE-I and ARB 
could lead to promising therapeutic approaches in BC treatment.

\section{Human studies reviewing the protective role of ACE-I/ARBs in BC treatment}

Although several in vivo and in vitro studies report protective effects of RAS inhibitors, results are inconsistent in clinical studies with human. Human studies reported mixed results on ACE-I and ARB use in improving overall BC outcomes (Table 2). While RAS inhibitors are used widely as antihypertensive drugs, their role as anti-cancer agent is not yet fully understood. ACE-I and ARBs have been found to demonstrate anti-inflammatory and proapoptotic activities in several preclinical studies of BC (Deshayes \& Nahmias 2005, Rosenthal \& Gavras 2009, George et al. 2010). However, clinical studies do not fully support these findings (Raimondi et al. 2016). A recent retrospective cohort study with $671 \mathrm{BC}$ patients reported inconsistent effects of ARBs on cancer prevalence and cancer-specific survival after 5-year follow-up. Here, only $7 \%$ of the total patients were using ARB and interestingly, though ARB-treated patients had a trend toward larger tumor size, the mean Ki-67-mediated BC aggressiveness was lower among ARB-treated patients. This conflicting data is possibly due to inclusion of both premenopausal and postmenopausal BC patients, inclusion of only ER-positive and EGFR-negative BC cases, and <10-year follow-up period of drug effects. The authors acknowledged that it was a single-center study which may be subjected to unknown bias and the findings cannot be generalized to overall population as ARB usage was studied only in patients with specific type of BC (Goldvaser et al. 2016). However, a recent meta-analyses of 21 observational studies reported a significantly reduced risk of BC with 10 or more years of ACE-I/ARB usage (Ni et al. 2017). Hence, the conflicting results of two studies mentioned above might be due to their (i) methods of data collection like retrospective in former versus prospective in later, (ii) follow-up time like $>10$ years in later versus $<10$ years in the former study, (iii) categorization of $\mathrm{BC}$ patients like ER+/EGFR- in the former versus all types of $\mathrm{BC}$ inclusion in the later, among all. All these variables could essentially skew the final findings of the studies mentioned earlier. Additionally, some studies reported possible RAS inhibitor-associated increases in different cancer risk and recurrence (Bangalore et al. 2011, Ganz et al. 2011). Sun et al. addressed these contradictory effects of RAS inhibitors on different cancer trials as being due to variability in drug doses, the type, and progressive stage of particular cancers (Sun et al. 2017). Other researchers have reported interesting roles of drug interactions among RAS inhibitors and COX-2 inhibitors. As prostaglandins and Ang II share common downstream effectors, such as the PI3K/AKT pathway (Barnes et al. 2007, Zhao et al. 2010), they can individually, or in combination (additively or synergistically), affect BC progression. Lee et al. reported beneficial effects of ACE-I in enhancing anti-tumor effects of both non-steroidal anti-inflammatory drugs (NSAID) and non-NSAIDs (Lee et al. 2012). By contrast, Holmes et al. reported that aspirin use is associated with a $50 \%$ reduced risk of cancer deaths, while ACE-I alone did not alter the risk of $\mathrm{BC}$ deaths in 4661 women between 30 and 55 years included in the Nurses' Health Study (NHS) with Stage I-III invasive BC. Interestingly, risk estimates for cancer deaths and recurrence were lowered significantly with a combination of aspirin and ACE-I (similar to aspirin alone), in a multivariate model of $\mathrm{BC}$ deaths and medication use. These findings indicate potent effects of aspirin, and its ability to override the null effects of ACE-I with BC deaths and recurrence (Holmes et al. 2013). Major limitations of these findings include retrospective nature of these studies, lack of follow-up studies, self-reported medication data, lack of adherence to drug usage, and inconsistent data on obesity status, smoking, family and hereditary history. Another combination was tested by Chae et al. who investigated individual and combined effects of ACE-I, ARBs and the cardioprotective drug, Statin, in reducing BC recurrence. They reported that ACE-I/ARB treatments significantly reduced $\mathrm{BC}$ recurrence in patients after a 4-year minimum follow-up, though there was no impact on overall cancer survival (Chae et al. 2011). Another study found favorable effects of ARB use on relapse-free BC survival (RFS) in patients undergoing neoadjuvant chemotherapy (Chae et al. 2013). Researchers found no association of ARB/ ACE-I use with overall and site-specific cancer risk from 15 combined trials of 138,769 participants with higher cardiovascular disease risk (ARB Trialists Collaboration, 2011). The only limitation of such observational studies is failure to follow-up patients for a long period of time. To summarize, the results from human studies indicate the need for more mechanistic studies involving cell, animal, and human models to identify and target the key variables responsible for $\mathrm{BC}$ cell growth, proliferation and metastasis.
C) 2019 Society for Endocrinology Published by Bioscientifica Ltd. Printed in Great Britain 


\section{Conclusions and future directions}

In this review, we have specifically focused on the potential mechanisms linking obesity, RAS and BC. The RAS is a possible link between obesity and BC interaction, as components of RAS are overexpressed in both obese and malignant cells, helping in the process of cell proliferation and growth. Activation of inflammatory pathways like NF- $\mathrm{kB}$ via Ang II and AT1R modulation have a major role in obesity-linked BC progression. Despite different adipokines, hormones and growth factors, adipocytederived Ang II can mediate its effect by BAT activation or WAT browning, which requires further research to understand RAS-mediated BAT action in obesity and $\mathrm{BC}$ crosstalk. Another potential research area is adiposemacrophage interaction in BC. Ang II is responsible for macrophage polarization and infiltration in both obesity and different tumor models. However, their mechanistic interaction is beyond the scope of this review.

In conclusion, obesity is a critical risk factor for developing $\mathrm{BC}$ especially in women after menopause. Obesity induces Ang II secretion, thereby promoting toxic tumor microenvironment. Overexpression of Ang II and its receptor AT1R is associated with many tumors, and activities like cell proliferation, angiogenesis, and inflammation. Hence, drugs blocking Ang II and AT1R interaction are of specific importance in altering adverse tumor outcomes. Although clinical and preclinical human studies report contradictory effects of ACE-I/ARB in BC, results available from cell and animal studies provide evidence of their beneficial effect on a mechanistic level. Given ongoing clinical use of RAS inhibitors, their feasibility and established safety as antihypertensives with minimum side effects, more in-depth investigations are warranted.

\section{Declaration of interest}

The authors declare that there is no conflict of interest that could be perceived as prejudicing the impartiality of this review.

\section{Funding}

This work was supported by start-up funds from Texas Tech University (TTU), Transdisciplinary Research Academy (obesity and breast cancer research), and the TTU Obesity Research Institute.

\section{References}

Alvarez A, Cerdá-Nicolás M, Nabah YNA, Mata M, Issekutz AC, Panés J, Lobb RR \& Sanz MJ 2004 Direct evidence of leukocyte adhesion in arterioles by angiotensin II. Blood 104 402-408. (https://doi. org/10.1182/blood-2003-08-2974)

Amaya K, Ohta T, Kitagawa H, Kayahara M, Takamura H, Fujimura T, Nishimura G-I, Shimizu K \& Miwa K 2004 Angiotensin II activates MAP kinase and NF-kB through angiotensin II type I receptor in human pancreatic cancer cells. International Journal of Oncology $\mathbf{2 5}$ 849-856. (https://doi.org/10.3892/ijo.25.4.849)

ARB Trialists Collaboration 2011 Effects of telmisartan, irbesartan valsartan, candesartan, and losartan on cancers in 15 trials enrolling 138,769 individuals. Journal of Hypertension 29 623-635. (https://doi. org/10.1097/HJH.0b013e328344a7de)

Arditi JD, Venihaki M, Karalis KP \& Chrousos GP 2007 Antiproliferative effect of adiponectin on MCF7 breast cancer cells: a potential hormonal link between obesity and cancer. Hormone and Metabolic Research 39 9-13. (https://doi.org/10.1055/s-2007-956518)

Austin D, Hamilton N, Elshimali Y, Pietras R, Wu Y \& Vadgama J 2018 Estrogen receptor-beta is a potential target for triple negative breast cancer treatment. Oncotarget 9 33912-33930. (https://doi. org/10.18632/oncotarget.26089)

Aziz SW \& Aziz MH 2013 Major signaling pathways involved in breast cancer. In Breast cancer metastasis and drug resistance. Berlin, Germany: Springer. (https://doi.org/10.1007/978-1-4614-5647-6_4)

Baggiolini M, Loetscher P \& Moser B 1995 Interleukin-8 and the chemokine family. International Journal of Immunopharmacology $\mathbf{1 7}$ 103-108. (https://doi.org/10.1016/0192-0561(94)00088-6)

Balkwill F, Charles KA \& Mantovani A 2005 Smoldering and polarized inflammation in the initiation and promotion of malignant disease. Cancer Cell 7 211-217. (https://doi.org/10.1016/j.ccr.2005.02.013)

Balkwill F \& Mantovani A 2001 Inflammation and cancer: back to Virchow? Lancet 357 539-545. (https://doi.org/10.1016/S01406736(00)04046-0)

Bangalore S, Kumar S, Kjeldsen SE, Makani H, Grossman E, Wetterslev J, Gupta AK, Sever PS, Gluud C \& Messerli FH 2011 Antihypertensive drugs and risk of cancer: network meta-analyses and trial sequential analyses of 324168 participants from randomised trials. Lancet. Oncology 12 65-82. (https://doi.org/10.1016/S1470-2045(10)70260-6)

Barnes NL, Warnberg F, Farnie G, White D, Jiang W, Anderson E \& Bundred NJ 2007 Cyclooxygenase-2 inhibition: effects on tumour growth, cell cycling and lymphangiogenesis in a xenograft model of breast cancer. British Journal of Cancer 96 575-582. (https://doi. org/10.1038/sj.bjc.6603593)

Biswas DK, Cruz AP, Gansberger E \& Pardee AB 2000 Epidermal growth factor-induced nuclear factor $\mathrm{\kappa B}$ activation: a major pathway of cellcycle progression in estrogen-receptor negative breast cancer cells. PNAS 97 8542-8547. (https://doi.org/10.1073/pnas.97.15.8542)

Bulun SE, Chen D, Moy I, Brooks DC \& Zhao H 2012 Aromatase, breast cancer and obesity: a complex interaction. Trends in Endocrinology \& Metabolism 23 83-89. (https://doi.org/10.1016/j.tem.2011.10.003)

Cantley LC 2002 The phosphoinositide 3-kinase pathway. Science 296 1655-1657. (https://doi.org/10.1126/science.296.5573.1655)

Cardwell CR, McMenamin ÚC, Hicks BM, Hughes C, Cantwell MM \& Murray LJ 2014 Drugs affecting the renin-angiotensin system and survival from cancer: a population based study of breast, colorectal and prostate cancer patient cohorts. BMC Medicine 12 28. (https:// doi.org/10.1186/1741-7015-12-28)

Cassis LA, English VL, Bharadwaj K \& Boustany CM 2004 Differential effects of local versus systemic angiotensin II in the regulation of leptin release from adipocytes. Endocrinology 145 169-174. (https:// doi.org/10.1210/en.2003-0767)

Catalán V, Gómez-Ambrosi J, Rodríguez A, Ramírez B, Ortega VA, Hernández-Lizoain JL, Baixauli J, Becerril S, Rotellar F, Valentí V, et al. 2017 IL-32 $\alpha$-induced inflammation constitutes a link between obesity and colon cancer. Oncoimmunology 6 e1328338. (https://doi. org/10.1080/2162402X.2017.1328338)

Catalano S, Giordano C, Panza S, Chemi F, Bonofiglio D, Lanzino M, Rizza P, Romeo F, Fuqua SA, Maggiolini M, et al. 2014 Tamoxifen 
through GPER upregulates aromatase expression: a novel mechanism sustaining tamoxifen-resistant breast cancer cell growth. Breast Cancer Research and Treatment 146 273-285. (https://doi.org/10.1007/ s10549-014-3017-4)

Chae YK, Brown EN, Lei X, Melhem-Bertrandt A, Giordano SH, Litton JK, Hortobagyi GN, Gonzalez-Angulo AM \& ChavezMacgregor M 2013 Use of ACE inhibitors and angiotensin receptor blockers and primary breast cancer outcomes. Journal of Cancer $\mathbf{4}$ 549-556. (https://doi.org/10.7150/jca.6888)

Chae YK, Valsecchi ME, Kim J, Bianchi AL, Khemasuwan D, Desai A \& Tester W 2011 Reduced risk of breast cancer recurrence in patients using ACE inhibitors, ARBs, and/or statins. Cancer Investigation 29 585-593. (https://doi.org/10.3109/07357907.2011.616252)

Che Q, Liu BY, Liao Y, Zhang HJ, Yang TT, He YY, Xia YH, Lu W, He XY, Chen Z, et al. 2014 Activation of a positive feedback loop involving IL-6 and aromatase promotes intratumoral $17 \beta$-estradiol biosynthesis in endometrial carcinoma microenvironment. International Journal of Cancer 135 282-294. (https://doi.org/10.1002/ijc.28679)

Chen X, Meng Q, Zhao Y, Liu M, Li D, Yang Y, Sun L, Sui G, Cai L \& Dong X 2013 Angiotensin II type 1 receptor antagonists inhibit cell proliferation and angiogenesis in breast cancer. Cancer Letters 328 318-324. (https://doi.org/10.1016/j.canlet.2012.10.006)

Cho WK, Shin SW, Kim SY, Hong CW, Choi C, Park W \& Noh JM 2016 Immunomodulatory effect of captopril and local irradiation on myeloid-derived suppressor cells. Radiation Oncology Journal $34223-$ 229. (https://doi.org/10.3857/roj.2016.01816)

Correa LH, Correa R, Farinasso CM, De Sant'ana Dourado LP \& Magalhaes KG 2017 Adipocytes and macrophages interplay in the orchestration of tumor microenvironment: new implications in cancer progression. Frontiers in Immunology 8 1129. (https://doi. org/10.3389/fimmu.2017.01129)

Dalamaga M, Karmaniolas K, Papadavid E, Pelekanos N, Sotiropoulos G \& Lekka A 2011 Elevated serum visfatin/nicotinamide phosphoribosyl-transferase levels are associated with risk of postmenopausal breast cancer independently from adiponectin, leptin, and anthropometric and metabolic parameters. Menopause 18 1198-1204. (https://doi.org/10.1097/gme.0b013e31821e21f5)

de Kloet AD, Krause EG, Scott KA, Foster MT, Herman JP, Sakai RR, Seeley RJ \& Woods SC 2011 Central angiotensin II has catabolic action at white and brown adipose tissue. American Journal of Physiology. Endocrinology and Metabolism 301 E1081-E1091. (https:// doi.org/10.1152/ajpendo.00307.2011)

De Paepe B, Verstraeten VL, De Potter CR, Vakaet LA \& Bullock GR 2001 Growth stimulatory angiotensin II type-1 receptor is upregulated in breast hyperplasia and in situ carcinoma but not in invasive carcinoma. Histochemistry and Cell Biology 116 247-254. (https://doi. org/10.1007/s004180100313)

De Paepe B, Verstraeten VM, De Potter CR \& Bullock GR 2002 Increased angiotensin II type-2 receptor density in hyperplasia, DCIS and invasive carcinoma of the breast is paralleled with increased iNOS expression. Histochemistry \& Cell Biology 117 13-19. (https://doi. org/10.1007/s00418-001-0356-0)

DeSantis C, Ma J, Bryan L \& Jemal A 2014 Breast cancer statistics, 2013. CA: A Cancer Journal for Clinicians 64 52-62. (https://doi. org/10.3322/caac.21203)

Deshayes F \& Nahmias C 2005 Angiotensin receptors: a new role in cancer? Trends in Endocrinology \& Metabolism 16 293-299. (https:// doi.org/10.1016/j.tem.2005.07.009)

Devore EE, Kim S, Ramin CA, Wegrzyn LR, Massa J, Holmes MD, Michels KB, Tamimi RM, Forman JP \& Schernhammer ES 2015 Antihypertensive medication use and incident breast cancer in women. Breast Cancer Research and Treatment 150 219-229. (https:// doi.org/10.1007/s10549-015-3311-9)

Dieudonne MN, Bussiere M, Dos Santos E, Leneveu MC, Giudicelli Y \& Pecquery R 2006 Adiponectin mediates antiproliferative and apoptotic responses in human MCF7 breast cancer cells. Biochemical and Biophysical Research Communications 345 271-279. (https://doi. org/10.1016/j.bbrc.2006.04.076)

Diez JJ \& Iglesias P 2003 The role of the novel adipocyte-derived hormone adiponectin in human disease. European Journal of Endocrinology 148 293-300. (https://doi.org/10.1530/eje.0.1480293)

Divella R, De Luca R, Abbate I, Naglieri E \& Daniele A 2016 Obesity and cancer: the role of adipose tissue and adipo-cytokines-induced chronic inflammation. Journal of Cancer 7 2346-2359. (https://doi. org/10.7150/jca.16884)

Doi C, Egashira N, Kawabata A, Maurya DK, Ohta N, Uppalapati D, Ayuzawa R, Pickel L, Isayama Y, Troyer D, et al. 2010 Angiotensin II type 2 receptor signaling significantly attenuates growth of murine pancreatic carcinoma grafts in syngeneic mice. BMC Cancer 1067. (https://doi.org/10.1186/1471-2407-10-67)

Du N, Feng J, Hu LJ, Sun X, Sun HB, Zhao Y, Yang YP \& Ren H 2012 Angiotensin II receptor type 1 blockers suppress the cell proliferation effects of angiotensin II in breast cancer cells by inhibiting AT1R signaling. Oncology Reports 27 1893-1903. (https://doi.org/10.3892/ or.2012.1720)

Dubois V, Jarde T, Delort L, Billard H, Bernard-Gallon D, Berger E, Geloen A, Vasson MP \& Caldefie-Chezet F 2014 Leptin induces a proliferative response in breast cancer cells but not in normal breast cells. Nutrition \& Cancer 66 645-655. (https://doi.org/10.1080/01635 581.2014.894104)

Egami K, Murohara T, Shimada T, Sasaki K-I, Shintani S, Sugaya T, Ishii M, Akagi T, Ikeda H, Matsuishi T, et al. 2003 Role of host angiotensin II type 1 receptor in tumor angiogenesis and growth. Journal of Clinical Investigation 112 67-75. (https://doi.org/10.1172/JCI16645)

Engeli S, Negrel R \& Sharma AM 2000 Physiology and pathophysiology of the adipose tissue renin-angiotensin system. Hypertension $\mathbf{3 5}$ 1270-1277. (https://doi.org/10.1161/01.hyp.35.6.1270)

Escobar E, Rodriguez-Reyna TS, Arrieta O \& Sotelo J 2004 Angiotensin II, cell proliferation and angiogenesis regulator: biologic and therapeutic implications in cancer. Current Vascular Pharmacology 2 385-399. (https://doi.org/10.2174/1570161043385556)

Esquitino VV, Danyel LA \& Steckelings UM 2015 The AT2 receptor and inflammation. In The Protective Arm of the Renin Angiotensin System (RAS), ch 13. Eds T Unger, UM Steckelings \& RAS Dos Santos. Boston, MA, USA: Academic Press.

Fain JN, Madan AK, Hiler ML, Cheema P \& Bahouth SW 2004 Comparison of the release of adipokines by adipose tissue, adipose tissue matrix, and adipocytes from visceral and subcutaneous abdominal adipose tissues of obese humans. Endocrinology 145 2273-2282. (https://doi.org/10.1210/en.2003-1336)

Ferrario CM, Ahmad S, Joyner J \& Varagic J 2010 Advances in the renin angiotensin system: focus on angiotensin-converting enzyme 2 and angiotensin-(1-7). Advances in Pharmacology 59 197-233. (https://doi. org/10.1016/S1054-3589(10)59007-0)

Floor SL, Dumont JE, Maenhaut C \& Raspe E 2012 Hallmarks of cancer: of all cancer cells, all the time? Trends in Molecular Medicine 18 509515. (https://doi.org/10.1016/j.molmed.2012.06.005)

Forrester SJ, Kawai T, O'Brien S, Thomas W, Harris RC \& Eguchi S 2016 Epidermal growth factor receptor transactivation: mechanisms, pathophysiology, and potential therapies in the cardiovascular system. Annual Review of Pharmacology and Toxicology 56 627-653. (https://doi.org/10.1146/annurev-pharmtox-070115-095427)

Gallagher PE \& Tallant EA 2004 Inhibition of human lung cancer cell growth by angiotensin-(1-7). Carcinogenesis 25 2045-2052. (https:// doi.org/10.1093/carcin/bgh236)

Ganz PA, Habel LA, Weltzien EK, Caan BJ \& Cole SW 2011 Examining the influence of beta blockers and ACE inhibitors on the risk for breast cancer recurrence: results from the LACE cohort. Breast Cancer Research and Treatment 129 549-556. (https://doi.org/10.1007/ s10549-011-1505-3)

García-Alonso V, Titos E, Alcaraz-Quiles J, Rius B, Lopategi A, LópezVicario C, Jakobsson PJ, Delgado S, Lozano J \& Clària J 2016 https://erc.bioscientifica.com

https://doi.org/10.1530/ERC-19-0314 (c) 2019 Society for Endocrinology Published by Bioscientifica Ltd. Printed in Great Britain 
Prostaglandin E2 exerts multiple regulatory actions on human obese adipose tissue remodeling, inflammation, adaptive thermogenesis and lipolysis. PLOS ONE 11 e0153751. (https://doi.org/10.1371/ journal.pone.0153751)

Gelsomino L, Naimo GD, Catalano S, Mauro L \& Ando S 2019 The emerging role of adiponectin in female malignancies. International Journal of Molecular Sciences 20 2127. (https://doi.org/10.3390/ ijms20092127)

George AJ, Purdue BW, Gould CM, Thomas DW, Handoko Y, Qian H, Quaife-Ryan GA, Morgan KA, Simpson KJ, Thomas WG, et al. 2013 A functional siRNA screen identifies genes modulating angiotensin II-mediated EGFR transactivation. Journal of Cell Science 1265377 5390. (https://doi.org/10.1242/jcs.128280)

George AJ, Thomas WG \& Hannan RD 2010 The renin-angiotensin system and cancer: old dog, new tricks. Nature Reviews. Cancer 10 745-759. (https://doi.org/10.1038/nrc2945)

Goel HL \& Mercurio AM 2013 VEGF targets the tumour cell. Nature Reviews. Cancer 13 871-882. (https://doi.org/10.1038/nrc3627)

Goldvaser H, Rizel S, Hendler D, Neiman V, Shepshelovich D, Shochat T, Sulkes A, Brenner B \& Yerushalmi R 2016 The association between angiotensin receptor blocker usage and breast cancer characteristics. Oncology 91 217-223. (https://doi.org/10.1159/000448479)

Greco S, Muscella A, Elia MG, Salvatore P, Storelli C, Mazzotta A, Manca C \& Marsigliante S 2003 Angiotensin II activates extracellular signal regulated kinases via protein kinase $\mathrm{C}$ and epidermal growth factor receptor in breast cancer cells. Journal of Cellular Physiology 196 370-377. (https://doi.org/10.1002/jcp.10313)

Guille A, Chaffanet M \& Birnbaum D 2013 Signaling pathway switch in breast cancer. Cancer Cell International 13 66. (https://doi. org/10.1186/1475-2867-13-66)

Guimond MO, Battista MC, Nikjouitavabi F, Carmel M, Barres V, Doueik AA, Fazli L, Gleave M, Sabbagh R \& Gallo-Payet N 2013 Expression and role of the angiotensin II AT2 receptor in human prostate tissue: in search of a new therapeutic option for prostate cancer. Prostate 73 1057-1068. (https://doi.org/10.1002/pros.22653)

Half E, Tang XM, Gwyn K, Sahin A, Wathen K \& Sinicrope FA 2002 Cyclooxygenase-2 expression in human breast cancers and adjacent ductal carcinoma in situ. Cancer Research 62 1676-1681.

Han J, Meng Q, Shen L \& Wu G 2018 Interleukin-6 induces fat loss in cancer cachexia by promoting white adipose tissue lipolysis and browning. Lipids in Health \& Disease 17 14. (https://doi.org/10.1186/ s12944-018-0657-0)

Herr D, Rodewald M, Fraser HM, Hack G, Konrad R, Kreienberg R \& Wulff C 2008 Potential role of renin-angiotensin-system for tumor angiogenesis in receptor negative breast cancer. Gynecologic Oncology 109 418-425. (https://doi.org/10.1016/j.ygyno.2008.02.019)

Hii SI, Nicol DL, Gotley DC, Thompson LC, Green MK \& Jonsson JR 1998 Captopril inhibits tumour growth in a xenograft model of human renal cell carcinoma. British Journal of Cancer 77 880-883. (https://doi.org/10.1038/bjc.1998.145)

Himbert C, Delphan M, Scherer D, Bowers LW, Hursting S \& Ulrich CM 2017 Signals from the adipose microenvironment and the obesitycancer link-A systematic review. Cancer Prevention Research 10494 506. (https://doi.org/10.1158/1940-6207.CAPR-16-0322)

Holmes MD, Hankinson SE, Feskanich D \& Chen WY 2013 Beta blockers and angiotensin-converting enzyme inhibitors' purported benefit on breast cancer survival may be explained by aspirin use. Breast Cancer Research and Treatment 139 507-513. (https://doi.org/10.1007/ s10549-013-2553-7)

Incio J, Ligibel JA, Mcmanus DT, Suboj P, Jung K, Kawaguchi K, Pinter M, Babykutty S, Chin SM, Vardam TD, et al. 2018 Obesity promotes resistance to anti-VEGF therapy in breast cancer by up-regulating IL-6 and potentially FGF-2. Science Translational Medicine 10 eaag0945. (https://doi.org/10.1126/scitranslmed. aag0945)
Inwang ER, Puddefoot JR, Brown CL, Goode AW, Marsigliante S, Ho MM, Payne JG \& Vinson GP 1997 Angiotensin II type 1 receptor expression in human breast tissues. British Journal of Cancer 75 12791283. (https://doi.org/10.1038/bjc.1997.217)

Ishimatsu S, Itakura A, Okada M, Kotani T, Iwase A, Kajiyama H, Ino K \& Kikkawa F 2006 Angiotensin II augmented migration and invasion of choriocarcinoma cells involves PI3K activation through the AT1 receptor. Placenta 27 587-591. (https://doi.org/10.1016/j. placenta.2005.07.001)

Iyengar NM, Hudis CA \& Dannenberg AJ 2013 Obesity and inflammation: new insights into breast cancer development and progression. American Society of Clinical Oncology Educational Book 2013 46-51. (https://doi.org/10.1200/EdBook_AM.2013.33.46)

Jarde T, Caldefie-Chezet F, Damez M, Mishellany F, Penault-Llorca F, Guillot J \& Vasson MP 2008 Leptin and leptin receptor involvement in cancer development: a study on human primary breast carcinoma. Oncology Reports 19 905-911. (https://doi.org/10.3892/ or.19.4.905)

Jezierska-Drutel A, Rosenzweig SA \& Neumann CA 2013 Role of oxidative stress and the microenvironment in breast cancer development and progression. Advances in Cancer Research 119 107125. (https://doi.org/10.1016/B978-0-12-407190-2.00003-4)

Kacinski BM 1995 CSF-1 and its receptor in ovarian, endometrial and breast cancer. Annals of Medicine 27 79-85. (https://doi. org/10.3109/07853899509031941)

Kalupahana NS, Massiera F, Quignard-Boulange A, Ailhaud G, Voy BH, Wasserman DH \& Moustaid-Moussa N 2012 Overproduction of angiotensinogen from adipose tissue induces adipose inflammation, glucose intolerance, and insulin resistance. Obesity 20 48-56. (https://doi.org/10.1038/oby.2011.299)

Kalupahana NS \& Moustaid-Moussa N 2012 The renin-angiotensin system: a link between obesity, inflammation and insulin resistance. Obesity Reviews 13 136-149. (https://doi. org/10.1111/j.1467-789X.2011.00942.x)

Kim S, Whelan J, Claycombe K, Reath DB \& Moustaid-Moussa N 2002 Angiotensin II increases leptin secretion by 3T3-L1 and human adipocytes via a prostaglandin-independent mechanism. Journal of Nutrition 132 1135-1140. (https://doi.org/10.1093/jn/132.6.1135)

Knight BB, Oprea-Ilies GM, Nagalingam A, Yang L, Cohen C, Saxena NK \& Sharma D 2011 Survivin upregulation, dependent on leptinEGFR-Notch1 axis, is essential for leptin-induced migration of breast carcinoma cells. Endocrine-Related Cancer 18 413-428. (https://doi. org/10.1530/ERC-11-0075)

Komine N, Khang S, Wead LM, Blantz RC \& Gabbai FB 2002 Effect of combining an ACE inhibitor and an angiotensin II receptor blocker on plasma and kidney tissue angiotensin II levels. American Journal of Kidney Diseases 39 159-164. (https://doi.org/10.1053/ ajkd.2002.29909)

Kurosaka M, Suzuki T, Hosono K, Kamata Y, Fukamizu A, Kitasato H, Fujita Y \& Majima M 2009 Reduced angiogenesis and delay in wound healing in angiotensin II type 1a receptor-deficient mice. Biomedicine \& Pharmacotherapy 63 627-634. (https://doi. org/10.1016/j.biopha.2009.01.001)

Lapeire L, Denys H, Cocquyt V \& De Wever O 2015 When fat becomes an ally of the enemy: adipose tissue as collaborator in human breast cancer. Hormone Molecular Biology \& Clinical Investigation 23 21-38. (https://doi.org/10.1515/hmbci-2015-0018)

Lee HH, Tsan YT, Ho WC, Lin MH, Lee CH, Tseng CD, Guo YL, Wang JD, Chen PC \& Health Data Analysis in Taiwan (hDATa) Research Group 2012 Angiotensin-converting enzyme inhibitors enhance the effect of cyclooxygenase inhibitors on breast cancer: a nationwide case-control study. Journal of Hypertension 30 2432-2439. (https://doi.org/10.1097/HJH.0b013e328358d42f)

Li FY, Cheng KK, Lam KS, Vanhoutte PM \& Xu A 2011 Cross-talk between adipose tissue and vasculature: role of adiponectin. Acta https://erc.bioscientifica.com

https://doi.org/10.1530/ERC-19-0314 (c) 2019 Society for Endocrinology Published by Bioscientifica Ltd. Printed in Great Britain 
Physiologica 203 167-180. (https://doi. org/10.1111/j.1748-1716.2010.02216.x)

Li XC \& Zhuo JL 2008 Nuclear factor-кB as a hormonal intracellular signaling molecule: focus on angiotensin II-induced cardiovascular and renal injury. Current Opinion in Nephrology and Hypertension 17 37-43. (https://doi.org/10.1097/MNH.0b013e3282f2903c)

Lim KT, Cosgrave N, Hill AD \& Young LS 2006 Nongenomic oestrogen signalling in oestrogen receptor negative breast cancer cells: a role for the angiotensin II receptor AT1. Breast Cancer Research 8 R33. (https://doi.org/10.1186/bcr1509)

Lorincz AM \& Sukumar S 2006 Molecular links between obesity and breast cancer. Endocrine-Related Cancer 13 279-292. (https://doi. org/10.1677/erc.1.00729)

Ma LJ, Corsa BA, Zhou J, Yang H, Li H, Tang YW, Babaev VR, Major AS, Linton MF, Fazio S, et al. 2011 Angiotensin type 1 receptor modulates macrophage polarization and renal injury in obesity. American Journal of Physiology. Renal Physiology 300 F1203-F1213. (https://doi.org/10.1152/ajprenal.00468.2010)

Mittal Y, Pavlova Y, Garcia-Marcos M \& Ghosh P 2011 Src homology domain 2-containing protein-tyrosine phosphatase-1 (SHP-1) binds and dephosphorylates $\mathrm{G}$ (alpha)-interacting, vesicle-associated protein (GIV)/Girdin and attenuates the GIV-phosphatidylinositol 3-kinase (PI3K)-Akt signaling pathway. Journal of Biological Chemistry 286 32404-32415. (https://doi.org/10.1074/jbc.M111.275685)

Monteiro R \& Azevedo I 2010 Chronic inflammation in obesity and the metabolic syndrome. Mediators of Inflammation 2010289645. (https://doi.org/10.1155/2010/289645)

Muscella A, Greco S, Elia M, Storelli C \& Marsigliante S 2002 Angiotensin II stimulation of $\mathrm{Na}+/ \mathrm{K}+$ ATPase activity and cell growth by calcium-independent pathway in MCF-7 breast cancer cells. Journal of Endocrinology 173 315-323. (https://doi.org/10.1677/ joe.0.1730315)

Namazi S, Rostami-Yalmeh J, Sahebi E, Jaberipour M, Razmkhah M \& Hosseini A 2014 The role of captopril and losartan in prevention and regression of tamoxifen-induced resistance of breast cancer cell line MCF-7: an in vitro study. Biomedicine \& Pharmacotherapy 68 565-571. (https://doi.org/10.1016/j.biopha.2014.05.004)

Napoleone E, Cutrone A, Cugino D, Amore C, Di Santo A, Iacoviello L, De Gaetano G, Donati MB \& Lorenzet R 2012 Inhibition of the renin-angiotensin system downregulates tissue factor and vascular endothelial growth factor in human breast carcinoma cells. Thrombosis Research 129 736-742. (https://doi.org/10.1016/j. thromres.2011.11.047)

Newman G \& Gonzalez-Perez RR 2014 Leptin-cytokine crosstalk in breast cancer. Molecular \& Cellular Endocrinology 382 570-582. (https://doi.org/10.1016/j.mce.2013.03.025)

Ni H, Rui Q, Zhu X, Yu Z, Gao R \& Liu H 2017 Antihypertensive drug use and breast cancer risk: a meta-analysis of observational studies. Oncotarget 8 62545-62560. (https://doi.org/10.18632/ oncotarget.19117)

Nouet S, Amzallag N, Li JM, Louis S, Seitz I, Cui TX, Alleaume AM, Di Benedetto M, Boden C, Masson M, et al. 2004 Trans-inactivation of receptor tyrosine kinases by novel angiotensin II AT2 receptorinteracting protein, ATIP. Journal of Biological Chemistry 279 28989-28997. (https://doi.org/10.1074/jbc.M403880200)

Oh E, Kim JY, Cho Y, An H, Lee N, Jo H, Ban C \& Seo JH 2016 Overexpression of angiotensin II type 1 receptor in breast cancer cells induces epithelial-mesenchymal transition and promotes tumor growth and angiogenesis. Biochimica \& Biophysica Acta 1863 1071-1081. (https://doi.org/10.1016/j.bbamcr.2016.03.010)

Pahlavani M, Kalupahana NS, Ramalingam L \& Moustaid-Moussa N 2017 Regulation and functions of the renin-angiotensin system in white and brown adipose tissue. Comprehensive Physiology 7 1137-1150. (https://doi.org/10.1002/cphy.c160031)

Patel SS \& Nakka S 2017 Protective effect of perindopril on tumor progression and angiogenesis in animal model of breast cancer. Anti-
Cancer Agents in Medicinal Chemistry 17 955-960. (https://doi.org/10. 2174/1871520616666160817143141)

Pei N, Mao Y, Wan P, Chen X, Li A, Chen H, Li J, Wan R, Zhang Y, Du H, et al. 2017 Angiotensin II type 2 receptor promotes apoptosis and inhibits angiogenesis in bladder cancer. Journal of Experimental \& Clinical Cancer Research: CR 36 77-77. (https://doi.org/10.1186/ s13046-017-0542-0)

Pettersson A \& Tamimi RM 2012 Breast fat and breast cancer. Breast Cancer Research and Treatment 135 321-323. (https://doi.org/10.1007/ s10549-012-2186-2)

Pfeiler GH, Buechler C, Neumeier M, Schaffler A, Schmitz G, Ortmann O \& Treeck O 2008 Adiponectin effects on human breast cancer cells are dependent on 17-beta estradiol. Oncology Reports 19 787-793.

Pickel L, Matsuzuka T, Doi C, Ayuzawa R, Maurya DK, Xie SX, Berkland C \& Tamura M 2010 Over-expression of angiotensin II type 2 receptor gene induces cell death in lung adenocarcinoma cells. Cancer Biology \& Therapy 9 277-285. (https://doi.org/10.4161/ cbt.9.4.10643)

Picon-Ruiz M, Morata-Tarifa C, Valle-Goffin JJ, Friedman ER \& Slingerland JM 2017 Obesity and adverse breast cancer risk and outcome: mechanistic insights and strategies for intervention. CA: A Cancer Journal for Clinicians 67 378-397. (https://doi.org/10.3322/ caac.21405)

Pierobon M \& Frankenfeld CL 2013 Obesity as a risk factor for triplenegative breast cancers: a systematic review and meta-analysis. Breast Cancer Research and Treatment 137 307-314. (https://doi.org/10.1007/ s10549-012-2339-3)

Pinter M \& Jain RK 2017 Targeting the renin-angiotensin system to improve cancer treatment: implications for immunotherapy. Science Translational Medicine 9 e5616. (https://doi.org/10.1126/scitranslmed. aan5616)

Pituskin E, Haykowsky M, Mackey JR, Thompson RB, Ezekowitz J, Koshman S, Oudit G, Chow K, Pagano JJ \& Paterson I 2011 Rationale and design of the Multidisciplinary Approach to Novel Therapies in Cardiology Oncology Research Trial (MANTICORE 101-Breast): a randomized, placebo-controlled trial to determine if conventional heart failure pharmacotherapy can prevent trastuzumab-mediated left ventricular remodeling among patients with HER2+ early breast cancer using cardiac MRI. BMC Cancer 11 318. (https://doi.org/10.1186/1471-2407-11-318)

Pollak MN, Schernhammer ES \& Hankinson SE 2004 Insulin-like growth factors and neoplasia. Nature Reviews. Cancer 4 505-518. (https://doi. org/10.1038/nrc1387)

Prontera C, Mariani B, Rossi C, Poggi A \& Rotilio D 1999 Inhibition of gelatinase A (MMP-2) by Batimastat and captopril reduces tumor growth and lung metastases in mice bearing Lewis lung carcinoma. International Journal of Cancer 81 761-766. (https://doi.org/10.1002/ (sici)1097-0215(19990531)81:5<761::aid-ijc16>3.0.co;2-1)

Puddefoot JR, Udeozo UK, Barker S \& Vinson GP 2006 The role of angiotensin II in the regulation of breast cancer cell adhesion and invasion. Endocrine-Related Cancer 13 895-903. (https://doi. org/10.1677/erc.1.01136)

Raimondi S, Botteri E, Munzone E, Cipolla C, Rotmensz N, Decensi A \& Gandini S 2016 Use of beta-blockers, angiotensin-converting enzyme inhibitors and angiotensin receptor blockers and breast cancer survival: systematic review and meta-analysis. International Journal of Cancer 139 212-219. (https://doi.org/10.1002/ijc.30062)

Ramalingam L, Menikdiwela K, Lemieux M, Dufour JM, Kaur G, Kalupahana N \& Moustaid-Moussa N 2017 The renin angiotensin system, oxidative stress and mitochondrial function in obesity and insulin resistance. Biochimica et Biophysica Acta. Molecular Basis of Disease 1863 1106-1114. (https://doi.org/10.1016/j. bbadis.2016.07.019)

Rhodes DR, Ateeq B, Cao Q, Tomlins SA, Mehra R, Laxman B, KalyanaSundaram S, Lonigro RJ, Helgeson BE, Bhojani MS, et al. 2009 AGTR1 overexpression defines a subset of breast cancer and confers https://erc.bioscientifica.com

https://doi.org/10.1530/ERC-19-0314
(C) 2019 Society for Endocrinology Published by Bioscientifica Ltd. Printed in Great Britain 
sensitivity to losartan, an AGTR1 antagonist. PNAS 10610284 10289. (https://doi.org/10.1073/pnas.0900351106)

Rinkenbaugh AL \& Baldwin AS 2016 The NF-kappaB pathway and cancer stem cells. Cells 5 16. (https://doi.org/10.3390/cells5020016)

Röcken C, Lendeckel U, Dierkes J, Westphal S, Carl-Mcgrath S, Peters B, Krüger S, Malfertheiner P, Roessner A \& Ebert MP 2005 The number of lymph node metastases in gastric cancer correlates with the angiotensin I-converting enzyme gene insertion/deletion polymorphism. Clinical Cancer Research 11 2526-2530. (https://doi. org/10.1158/1078-0432.CCR-04-1922)

Rodrigues-Ferreira S, Molina A, Nehlig A \& Nahmias C 2015 The AT2 receptor and interacting proteins (ATIPs) in cancer. In The Protective Arm of the Renin Angiotensin System (RAS), ch 14. Eds T Unger, UM Steckelings \& RAS Dos Santos. Boston, MA, USA: Academic Press.

Rodrigues-Ferreira S, Morel M, Reis RI, Cormier F, Baud V, CostaNeto CM \& Nahmias C 2012 A novel cellular model to study angiotensin II AT2 receptor function in breast cancer cells. International Journal of Peptides 2012 745027. (https://doi. org/10.1155/2012/745027)

Rodrigues-Ferreira S \& Nahmias C 2015 G-protein coupled receptors of the renin-angiotensin system: new targets against breast cancer? Frontiers in Pharmacology 6 24. (https://doi.org/10.3389/ fphar.2015.00024)

Rosenthal T \& Gavras I 2009 Angiotensin inhibition and malignancies: a review. Journal of Human Hypertension 23 623-635. (https://doi. org $/ 10.1038 /$ jhh.2009.21)

Saely CH, Geiger K \& Drexel H 2012 Brown versus white adipose tissue: a mini-review. Gerontology 58 15-23. (https://doi. org/10.1159/000321319)

Samal B, Sun Y, Stearns G, Xie C, Suggs S \& Mcniece I 1994 Cloning and characterization of the cDNA encoding a novel human pre-Bcell colony-enhancing factor. Molecular and Cellular Biology 14 14311437. (https://doi.org/10.1128/mcb.14.2.1431)

Samarajeewa NU, Yang F, Docanto MM, Sakurai M, Mcnamara KM, Sasano H, Fox SB, Simpson ER \& Brown KA 2013 HIF-1 $\alpha$ stimulates aromatase expression driven by prostaglandin $\mathrm{E} 2$ in breast adipose stroma. Breast Cancer Research 15 R30. (https://doi.org/10.1186/ bcr3410)

Saxena NK, Taliaferro-Smith L, Knight BB, Merlin D, Anania FA, O'Regan RM \& Sharma D 2008 Bidirectional crosstalk between leptin and insulin-like growth factor-I signaling promotes invasion and migration of breast cancer cells via transactivation of epidermal growth factor receptor. Cancer Research 68 9712-9722. (https://doi. org/10.1158/0008-5472.CAN-08-1952)

Scheen AJ 2004 Prevention of type 2 diabetes mellitus through inhibition of the renin-angiotensin system. Drugs $\mathbf{6 4} 2537-2565$. (https://doi.org/10.2165/00003495-200464220-00004)

Seibold P, Hein R, Schmezer P, Hall P, Liu J, Dahmen N, Flesch-Janys D, Popanda O \& Chang-Claude J 2011 Polymorphisms in oxidative stress-related genes and postmenopausal breast cancer risk. International Journal of Cancer 129 1467-1476. (https://doi. org/10.1002/ijc.25761)

Shostak K \& Chariot A 2015 EGFR and NF-kappaB: partners in cancer. Trends in Molecular Medicine 21 385-393. (https://doi.org/10.1016/j. molmed.2015.04.001)

Simone V, D'avenia M, Argentiero A, Felici C, Rizzo FM, De Pergola G \& Silvestris F 2016 Obesity and breast cancer: molecular interconnections and potential clinical applications. Oncologist 21 404-417. (https://doi.org/10.1634/theoncologist.2015-0351)

Simpson ER \& Brown KA 2013 Minireview: obesity and breast cancer: a tale of inflammation and dysregulated metabolism. Molecular Endocrinology 27 715-725. (https://doi.org/10.1210/me.2013-1011)

Singh R, Parveen M, Basgen JM, Fazel S, Meshesha MF, Thames EC, Moore B, Martinez L, Howard CB, Vergnes L, et al. 2016 Increased expression of Beige/Brown adipose markers from host and breast cancer cells influence xenograft formation in mice. Molecular Cancer
Research 14 78-92. (https://doi.org/10.1158/1541-7786.MCR-150151)

Skurk T, Van Harmelen V, Blum WF \& Hauner H 2005 Angiotensin II promotes leptin production in cultured human fat cells by an ERK1/2-dependent pathway. Obesity Research 13 969-973. (https:// doi.org/10.1038/oby.2005.113)

Slinker BK, Wu Y, Brennan AJ, Campbell KB \& Harding JW 1999 Angiotensin IV has mixed effects on left ventricle systolic function and speeds relaxation. Cardiovascular Research 42 660-669. (https:// doi.org/10.1016/s0008-6363(98)00344-7)

Small W, Molteni A, Kim YT, Taylor JM, ts'ao CH \& Ward WF 1999 Mechanism of captopril toxicity to a human mammary ductal carcinoma cell line in the presence of copper. Breast Cancer Research and Treatment $\mathbf{5 5}$ 223-229. (https://doi. org/10.1023/a:1006233521325)

Smith TA, Phyu SM \& Akabuogu EU 2016 Effects of administered cardioprotective drugs on treatment response of breast cancer cells. Anticancer Research 36 87-93.

Somasundar P, Mcfadden DW, Hileman SM \& Vona-Davis L 2004 Leptin is a growth factor in cancer. Journal of Surgical Research 116 337-349. (https://doi.org/10.1016/j.jss.2003.09.004)

Song S, Su Z, Xu H, Niu M, Chen X, Min H, Zhang B, Sun G, Xie S, Wang H, et al. 2017 Luteolin selectively kills STAT3 highly activated gastric cancer cells through enhancing the binding of STAT3 to SHP1. Cell Death \& Disease 8 e2612. (https://doi.org/10.1038/ cddis.2017.38)

Stephenson GD \& Rose DP 2003 Breast cancer and obesity: an update. Nutrition and Cancer 45 1-16. (https://doi.org/10.1207/ S15327914NC4501_1)

Subbaram S \& Dipersio CM 2011 Integrin alpha3beta1 as a breast cancer target. Expert Opinion on Therapeutic Targets 15 1197-1210. (https:// doi.org/10.1517/14728222.2011.609557)

Subbaramaiah K, Morris PG, Zhou XK, Morrow M, Du B, Giri D, Kopelovich L, Hudis CA \& Dannenberg AJ 2012 Increased levels of COX-2 and prostaglandin E2 contribute to elevated aromatase expression in inflamed breast tissue of obese women. Cancer Discovery 2 356-365. (https://doi.org/10.1158/2159-8290.CD-110241)

Suganuma T, Ino K, Shibata K, Kajiyama H, Nagasaka T, Mizutani S \& Kikkawa F 2005 Functional expression of the angiotensin II type1 receptor in human ovarian carcinoma cells and its blockade therapy resulting in suppression of tumor invasion, angiogenesis, and peritoneal dissemination. Clinical Cancer Research 11 2686-2694. (https://doi.org/10.1158/1078-0432.CCR-04-1946)

Sun H, Li T, Zhuang R, Cai W \& Zheng Y 2017 Do renin-angiotensin system inhibitors influence the recurrence, metastasis, and survival in cancer patients?: evidence from a meta-analysis including 55 studies. Medicine 96 e6394. (https://doi.org/10.1097/ MD.0000000000006394)

Suzuki R, Orsini N, Saji S, Key TJ \& Wolk A 2009 Body weight and incidence of breast cancer defined by estrogen and progesterone receptor status - a meta-analysis. International Journal of Cancer 124 698-712. (https://doi.org/10.1002/ijc.23943)

Tahmasebi M, Barker S, Puddefoot JR \& Vinson GP 2006 Localisation of renin-angiotensin system (RAS) components in breast. British Journal of Cancer 95 67-74. (https://doi.org/10.1038/sj.bjc.6603213)

Todorović-Raković N \& Milovanović J 2013 Interleukin-8 in breast cancer progression. Journal of Interferon \& Cytokine Research 33 563570. (https://doi.org/10.1089/jir.2013.0023)

Tremblay AM, Dufour CR, Ghahremani M, Reudelhuber TL \& Giguère V 2010 Physiological genomics identifies estrogen-related receptor alpha as a regulator of renal sodium and potassium homeostasis and the renin-angiotensin pathway. Molecular Endocrinology 24 22-32. (https://doi.org/10.1210/me.2009-0254)

Uemura H, Hasumi H, Ishiguro H, Teranishi JI, Miyoshi Y \& Kubota Y 2006 Renin-angiotensin system is an important factor in hormone (c) 2019 Society for Endocrinology Published by Bioscientifica Ltd. Printed in Great Britain 
refractory prostate cancer. Prostate 66 822-830. (https://doi. org/10.1002/pros.20407)

Uemura H, Ishiguro H, Ishiguro Y, Hoshino K, Takahashi S \& Kubota Y 2008 Angiotensin II induces oxidative stress in prostate cancer. Molecular Cancer Research 6 250-258. (https://doi.org/10.1158/15417786.MCR-07-0289)

Van Uden P, Kenneth NS \& Rocha S 2008 Regulation of hypoxiainducible factor- $1 \alpha$ by NF-кB. Biochemical Journal 412 477-484. (https://doi.org/10.1042/BJ20080476)

Vinson GP, Barker S \& Puddefoot JR 2012 The renin-angiotensin system in the breast and breast cancer. Endocrine-Related Cancer 19 R1-R19. (https://doi.org/10.1530/ERC-11-0335)

Walter M, Liang S, Ghosh S, Hornsby PJ \& Li R 2009 Interleukin 6 secreted from adipose stromal cells promotes migration and invasion of breast cancer cells. Oncogene 28 2745-2755. (https://doi. org/10.1038/onc.2009.130)

Wang CH, Wang PJ, Hsieh YC, Lo S, Lee YC, Chen YC, Tsai CH, Chiu WC, Chu-Sung HU, Lu S, et al. 2017 Resistin facilitates breast cancer progression via TLR4-mediated induction of mesenchymal phenotypes and stemness properties. Oncogene 37 589-600. (https:// doi.org/10.1038/onc.2017.357)

Wang D \& Dubois RN 2012 The role of the $\mathrm{PGE}_{2}$-aromatase pathway in obesity-associated breast inflammation. Cancer Discovery 2 308-310. (https://doi.org/10.1158/2159-8290.CD-12-0078)

Wang F, Gao S, Chen F, Fu Z, Yin H, Lu X, Yu J \& Lu C 2014 Mammary fat of breast cancer: gene expression profiling and functional characterization. PLOS ONE 9 e109742. (https://doi.org/10.1371/ journal.pone.0109742)

Wang H, Chu WS, Hemphill C \& Elbein SC 2002 Human resistin gene: molecular scanning and evaluation of association with insulin sensitivity and Type 2 diabetes in Caucasians. Journal of Clinical Endocrinology \& Metabolism 87 2520-2524. (https://doi.org/10.1210/ jcem.87.6.8528)

Wortman P, Miyazaki Y, Kalupahana NS, Kim S, Hansen-Petrik M, Saxton AM, Claycombe KJ, Voy BH, Whelan J \& Moustaid-Moussa N $2009 \mathrm{n} 3$ and n6 polyunsaturated fatty acids differentially modulate prostaglandin E secretion but not markers of lipogenesis in adipocytes. Nutrition \& Metabolism 6 5-5. (https://doi. org/10.1186/1743-7075-6-5)

Wu JT \& Kral JG 2005 The NF-kB/IкB signaling system: a molecular target in breast cancer therapy. Journal of Surgical Research 123158 169. (https://doi.org/10.1016/j.jss.2004.06.006)

Xi B, Zeng T, Liu L, Liang Y, Liu W, Hu Y \& Li J 2011 Association between polymorphisms of the renin-angiotensin system genes and breast cancer risk: a meta-analysis. Breast Cancer Research \& Treatment 130 561-568. (https://doi.org/10.1007/s10549-011-1602-3)

Xue Q, Xiao D \& Zhang L 2015 Estrogen regulates angiotensin II receptor expression patterns and protects the heart from ischemic injury in female rats. Biology of Reproduction 93 6. (https://doi. org/10.1095/biolreprod.115.129619)

Yan Y, Jiang X, Zhao Y, Wen H \& Liu G 2015 Role of GPER on proliferation, migration and invasion in ligand-independent manner in human ovarian cancer cell line SKOV3. Cell Biochemistry and Function 33 552-559. (https://doi.org/10.1002/cbf.3154)

Yoshiji H, Noguchi R, Kaji K, Ikenaka Y, Shirai Y, Namisaki T, Kitade M, Tsujimoto T, Kawaratani H \& Fukui H 2010 Attenuation of insulinresistance-based hepatocarcinogenesis and angiogenesis by combined treatment with branched-chain amino acids and angiotensinconverting enzyme inhibitor in obese diabetic rats. Journal of Gastroenterology 45 443-450. (https://doi.org/10.1007/s00535-0090158-z)

Yuan HJ, Sun KW \& Yu K 2014 Leptin promotes the proliferation and migration of human breast cancer through the extracellular-signal regulated kinase pathway. Molecular Medicine Reports 9 350-354. (https://doi.org/10.3892/mmr.2013.1786)

Yvan-Charvet L \& Quignard-Boulange A 2011 Role of adipose tissue renin-angiotensin system in metabolic and inflammatory diseases associated with obesity. Kidney International 79 162-168. (https://doi. org/10.1038/ki.2010.391)

Zahid H, Simpson ER \& Brown KA 2016 Inflammation, dysregulated metabolism and aromatase in obesity and breast cancer. Current Opinion in Pharmacology 31 90-96. (https://doi.org/10.1016/j. coph.2016.11.003)

Zhang L, Cheng J, Thomas Y, Zhang W, \& Du J 2005 Dual pathways for nuclear factor $\mathrm{\kappa B}$ activation by angiotensin II in vascular smooth muscle: phosphorylation of p65 by IкB kinase and ribosomal kinase. Circulation Research 97 975-982. (https://doi.org/10.1161/01. RES.0000190589.52286.41)

Zhao Y, Chen X, Cai L, Yang Y, Sui G \& Fu S 2010 Angiotensin II/ angiotensin II type I receptor (AT1R) signaling promotes MCF-7 breast cancer cells survival via PI3-kinase/Akt pathway. Journal of Cellular Physiology 225 168-173. (https://doi.org/10.1002/ jср.22209)

Zhao Y, Chen X, Cai L, Yang Y, Sui G \& Wu J 2008 Angiotensin II suppresses adriamycin-induced apoptosis through activation of phosphatidylinositol 3-kinase/Akt signaling in human breast cancer cells. Acta Biochimica et Biophysica Sinica 40 304-310. (https://doi. org/10.1111/j.1745-7270.2008.00402.x)

Received in final form 10 September 2019

Accepted 16 September 2019

Accepted Preprint published online 16 September 2019
C) 2019 Society for Endocrinology Published by Bioscientifica Ltd. Printed in Great Britain 